\title{
Agility Versus Flexibility? The Perception of Business Model Maturity in Agricultural Machinery Sector Manufacturing Companies
}

\author{
Bogdan Nogalskil, Przemysław Niewiadomski², Agnieszka A. Szpitter ${ }^{3}$
}

Submitted: 5.03.20. Accepted: 31.08.20

\section{Abstract}

Purpose: The fundamental objective of this article is to discern whether business model maturity is perceived through the prism of the ability to deal with unexpected challenges, overcome unprecedented threats, and use emerging business opportunities (agility) or - perhaps - more as a feature of the organization, which makes a business model less vulnerable to unpredictable external changes or sets it in a better position to make it respond effectively to these changes (flexibility).

Methodology: The reconnaissance of opinions requires the creation of a catalog of desiderata that significantly identify agility and flexibility. Theoretical and design layers will use a method of reconstruction and interpretation of the subject literature supported by a discussion within a group of deliberately selected experts. This will be reflected in a set of parameters, on the one hand, characteristic of the categories of agility and flexibility and, on the other hand, reflecting business model maturity.

Findings: The conducted research allows us to state that mature business models - as implemented by the surveyed companies - are perceived rather through the prism of the strategic ability of enterprises to quickly adapt to unforeseen and sudden changes on the market (agility category).

Originality: The article includes not only academic postulates of agility or flexibility but also practical tips that enable constructing guidelines for decision-makers and managers of the agricultural machinery sector. The study carries a charge of a theoretical and empirical study. It takes into account knowledge and expert experience.

Keywords: agility, flexibility, maturity, business model.

\section{JEL: L11, M31, M15}

\footnotetext{
1 WSB University in Gdańsk, Institute of Management and Finance; Aleja Grunwaldzka 238A, 80-266 Gdańsk, Poland, e-mail: bogdannogalski.bn@gmail.com, https:// orcid.org/0000-0003-0262-8355.

2 The University of Zielona Góra, Faculty of Economics and Management; 50 Podgórna St., 65-246 Zielona Góra, Poland, e-mail: p.niewiadomski@wez.uz.zgora.pl, https:// orcid.org/0000-0002-2805-4671.

3 The University of Gdańsk, Faculty of Management, Organization and Management Institute; 101 Armii Krajowej St., 81-824 Sopot; e-mail: agnieszka.szpitter@ug.edu.pl, https:// orcid.org/0000-0002-3571-7234.
} 


\section{Introduction}

The current times are accompanied by profound social and structural changes in the global dimension, strongly determining all actions and shaping the economic sphere of life. The companies wishing to achieve a market success must meet the demands of the modern economy, characterized by network connections, the high variability of operating conditions, and the rapid development of new technologies (Industry 4.0). This means that organizations - or, rather, their managers - face new challenges that need to be addressed (Breu et al., 2001; Barrand, 2006).

To maintain a competitive advantage on the market, companies must efficiently adapt their operations, striving to dynamically and efficiently respond to market needs. One ought to endeavor to verify a given situation, assess opportunities, and choose objectives and rules for the use of resources. Scholarship postulates the application of a set of techniques and methods of analysis and synthesis that enable the implementation of these aspirations and to collect the necessary information. It is vital to demonstrate the will to constantly change the areas and methods of the enterprise operation in accordance with changes in company vision and the state of its current environment (Jemielniak, Latusek, 2005; Jemielniak and Koźmiński, 2011). This should also be implemented by striving to eliminate the limitations of leadership that affect its effectiveness (Korzyński, 2014; Koźmiński, 2013; Yukl, 2012). New challenges require a new approach alongside new tools. What remains unchanged is the human context and the need to adopt a perspective that places people and their needs at the center of the process (Korzyński, 2013).

Especially in the industrial sector, more and more complex challenges arise in the human, technological, manufacturing, and business areas. The fourth industrial revolution affects the entire area of company operations, so it does not suffice to introduce only technological changes, as equally crucial becomes the implementation of a well-prepared strategy (cf. Obłój, 2014; Obłój, 2016; Obłój, 2017). Modern management responds to increasingly individualized customer needs and the reorientation of mass production to a personalized one while maintaining costs similar to mass production. All this is feasible, owing to the application of innovative solutions on production lines and significant changes in terms of enterprise management.

The observation and drawing of the right conclusions, along with undertaking adequate remedial actions, may determine company survival. Scholars generally advocate a thesis that due to the rapid pace of changes in company operating conditions, all actions should be pre-emptive, i.e. they should be taken and directed towards future anticipated environmental conditions (Nichols, 2012). The difficulty remains that with 
such varying surrounding conditions (non-linear operating conditions), predictions can be unreliable. Hence, it is vital to create "adaptive" organizations capable of responding flexibly or agilely to changing non-linear external conditions.

Given the empirical evidence confirming the existence of a strong relationship between the market success of enterprises and a mature business model (Lockamy and McCormack, 2004; Nenni et al., 2014; Sehnem et al., 2019), the current article's research direction increases agility and flexibility to the attribute titer of its "maturity." This means that a mature business model is recognized, on the one hand, as a critical and decisive factor for the survival of a company and, on the other hand, as one that implies the possibility of development under complicated and uncertain operating conditions.

Even though the subject literature analysis shows that the research so far has been conducted to consider agility or flexibility in the domain of adaptation activities (Nickpour and Salajegheh, 2011; Mehrabi, 2013; Nabatchian, 2014; Niewiadomski, 2016), the inference was based mainly on literature research or empirical research conducted in enterprises from various sectors of the economy (Darvishmotevali, Altinay, and Köseoglu, 2020). For various reasons, no comprehensive, result-based research related to the agricultural machinery sector was undertaken. Striving to fill the existing knowledge gap, we conducted a series of studies, whose results we present in this article.

Based on a widespread discussion that recently happened in the milieu of management scientists and practitioners, we postulate that there once again arises the question about the stage of maturity implementation. Seeking to fill the existing knowledge gap, we conducted a series of studies that attempted to assess the implementation of selected flexibility and agility desiderata. In-depth studies in the area of the above problem, own observations of economic practice, and conducted empirical research led to the formulation of specific questions, whose solution answered the main problem:

- Should the fundamental dimensions of agility and flexibility be taken into account when conceptualizing the idea of a mature business model?

- What is the level of implementation - determining agility and flexibility - of the desiderata that determine the maturity of a business model?

- Can we hierarchize desiderata of agility and flexibility that determine the maturity of production company business model operating within the agricultural machinery sector?

The main issue of this study, reflecting the described problem situation and directing research activities, is the lack of recognition and comprehensive ordering of descrip- 
tors that determine flexibility and agility from the perspective of the maturity of the business model.

In this context, we should mention that among numerous attempts to distinguish organizational agility from flexibility, there are those that indicate the superiority of the former over the latter (Raschke, 2010; Trzcieliński, 2011; Faratash and Davoudi, 2012; Goriwondo, Mhlanga, and Mutsambwa, 2013), but also those that combine the two (Bernardes and Hanna, 2009; Swafford, Ghosh, and Murthy, 2006). In many developments, it is possible to observe that the concept of agility is not used anymore in aid of flexibility (Brown, Pham, and Sivabalan, 2020; Niewiadomski, 2016), which is usually accompanied by the introduction of uniform understanding.

Despite many common features that are characteristic of both concepts, the fundamental objective of this article was stated to be the recognition whether the business model maturity is perceived through the prism of the capacity to deal with unexpected challenges, overcoming unprecedented threats, and using emerging business opportunities (agility) or - perhaps - more as a feature of the organization, which makes a business model less vulnerable to unpredictable external changes or sets it in a better position to effectively respond to these changes (flexibility). The reconnaissance of opinions requires - first and foremost - the creation of a catalog of desiderata, significantly identifying agility and flexibility. The theoretical and design layers will use the method of reconstruction and interpretation of the subject literature supported (Czakon, 2011) by a discussion within a group of deliberately selected experts (Paulus et al., 1993; Rhodes, 1987). This will be reflected in the set of parameters, on the one hand, characteristic of the category of agility and flexibility and, on the other hand, reflecting the business model maturity (Osterwalder, Pigneur, and Tucci, 2005). At the empirical level, we should determine to what extent do the suggested properties reflect the meaning of the concept in the context of an intensive search of market opportunities that emerge in the environment. It seems that the complexity of problems and the lack - so far - of scientific identification justify our consideration of the mentioned issues as the research subject.

The formulated questions and belief in the existence of economic demand for results of application nature, on the one hand, were the main inspiration to undertake the research and, on the other hand, they became the starting point for formulating the following leading presumption: as more and more companies appreciate the business model, in which the concept of agile and flexible enterprise is the reference point, the maturity of the business model is mainly viewed through the prism of capacity to deal with unexpected challenges, overcoming unprecedented threats, and using emerging business opportunities (agility). 
In the conducted argument, we refer to the concept of sustainable enterprise, that is, the concept of a future company that flexibly adapts to continuous and turbulent changes in the environment, capable of functioning under conditions of crisis and chaos. The current article includes not only academic postulates of agility or flexibility but also practical tips that enable the construction of guidelines for decision-makers and managers in the agricultural machinery sector. The study carries a charge of a theoretical and empirical study. It takes into account knowledge and expert experience. When solving research problems and verifying the presumption, we take advantage of experts' achievements in the field of management and quality sciences; hence, based on the current nomenclature, our considerations in this article fall within the social sciences.

\section{Agility versus Flexibility: Similarities and Differences}

Modern times are characterized by the widespread changeability of various aspects of reality and the resulting cumulative complexity of relations between its components. On the one hand, this raises the need to explain phenomena and their effects and, on the other hand, expedites the theory outdating process that would satisfy this need. This also triggers various discrepancies in the theory and practice expectations formed by management sciences. These dissonances concern, among other things, theories and practices in the field of agility (Yusuf, Sarhadi, and Gunasekaran, 1999; Sharifi et al., 2001) and flexibility management (Norman and Stockport, 2009; Zheng and Wu, 2010). The accelerated process of some theories becoming obsolete caused by the variability of conditions of their application also initiates difficulties in verifying their scientificity, thus distinguishing between real and true concepts and methods from those on the market of fashion and quasi-scientific products. Another problem is the temporal dissonance between expectations of practice and the offer of science in the form of indications and concepts for the functioning and development of the organization under postmodern conditions.

At this point, we postulate that the first step in establishing the theory of management and quality sciences should be the adoption of a new theoretical framework, in which one could logically group together statements that make up the theory of flexibility and agility management within the organization. We hope that this article will - at least to a minimal extent - help others to visualize the relationships between these concepts. Despite the difficulty of the issue and any possibility of proposing an alternative positive solution, we offer a starting point for discussion - not a definitive position. 
Management theory and practice show that a single definition of flexibility is far from common acceptance. Despite many attempts to establish positions among the researchers, there is no clear consensus on the meaning of this concept. In the context of the above, D. Gerwin (1987) proposes that flexibility is the ability to effectively respond to the environment. A slightly broader definition is presented by A. Sethi and S. Sethi (1990), who define company flexibility as the ability to reallocate production resources so as to efficiently manufacture products while providing acceptable quality. The resourcebased approach in its definition is also highlighted by J. Olagher (1993), who states that short-term flexibility means the ability to adapt to changing conditions with the use of existing resources.

Long-term flexibility is perceived in a slightly different way. It measures the ability to introduce new products, new resources, manufacturing methods, and their integration with the existing manufacturing systems. The manufacturing system's ability to change or respond when incurring low outlays from the perspective of time, cost, or results of activities is flexibility, according to Upton (1994). In particular, flexibility refers to the use of organization resources: tangible (property, financial) and intangible (informational, relational). These are the resources that are the main tool for shaping the flexibility of the organization as a whole. In the context of the cited definition, Krupski (2005) notices that flexibility is a reaction to stimuli from the environment or from inside the company; it faces the resource potential of the organization, including the possibility of access to foreign resources.

In the subject literature, organizational flexibility is often identified with the ability to adapt the entire organization, without mentioning the areas it applies to (Lynch, 1989). In other approaches of organization flexibility, there is a detailed method of its achievement and a detailed area it applies to (Ng and Dastmalchian, 2001).

Within the framework of the literature analysis, we find general and specific definitions that describe only its selected aspects and refer to any organization. The above flexibility definitions are the context of various approaches that can be found in the subject literature. The company flexibility definition is like specifying many other key categories or concepts in the field of economics or management. There is a multitude of definitions, there is also a lack of uniformity, and there even is the use of the same concept to define various phenomena, which consequently leads to many misunderstandings in their interpretation. Such situations are also hindered by the occurrence of synonyms. A related term of flexibility is agility. It is not an isolated situation that concepts of flexibility and agility are treated as synonyms (Stańczyk-Hugiet, 2008). Like 
flexibility, agility is sometimes defined within an organization as having the ability to quickly respond to changes (opportunities and threats) by occurring in a turbulent environment to maintain its competitiveness. In the context of the above, we should note that agility and flexibility are features required for any company that operates in a new business environment conditions and wants to survive. The ability to strategically respond to new criteria of the business environment in practice means the use of methods, manufacturing, and organizational processes, practices, and tools so far mostly already developed.

The relationships between flexibility and agility were analyzed, among others, by Baker (1996). In his opinion, company flexibility appeared as a reaction of companies to excessive specialization within the area of operational activity; however, the assessment of a company's agility came about as a result of government research on the sources of competitiveness of companies, conducted in the 1990s in the United Kingdom and the United States of America. At this point, we should note that in all the variety of definitions, both flexibility and agility of the company, a narrowed or extended scope of its meaning is perceived.

According to Urbanowska-Sojkin (2013), company agility was originally defined as the organization's ability to effectively function in a constantly changing and unpredictable business environment. The concept of company agility was defined by Dove in 1999, who recognized that this is a management concept directly linked with the decision-making process, linked to the use of held knowledge as accessed through company information architecture. Hence, agility means the ability to survive and cope in a competitive environment full of unpredictable changes, which requires a rapid and effective reaction to market changes (Gunasekaran, 1998). In order to meet client requirements in the changing market, the company must take quick action that enables it to maintain a competitive advantage. Thus, the situation forces the acceptance of innovations in the manufacturing process, along with information and communication technologies that require the reorganization of the company and the adoption of new marketing strategies. Sharifi and Zhang (1999) define company agility as the ability to cope with unexpected challenges, overcome unprecedented threats, and make use of emerging business opportunities. According to Trzcieliński (2011), agility focuses on the use of market opportunities, which on the one hand, requires the prior implementation of agility and methods relevant to lean enterprises and, on the other hand, the use of various management models and methods implementing agility. In light of the above, we note that agility can be treated as a concept constituting a lean enterprise, which is limited only to the concept and methods that are the common part of both concepts. 
Pursuant to the strategy model proposed by Brown and Eisenhardt (1998) for companies operating on the brink of chaos, it is important to assume that the increasing turbulence of the environment determines the management of change as the central and most important challenge of strategic management. Therefore, the company's strategy should allow for the construction of the organization (structure, processes, systems) that can change in a continuous and effective way. The company's ability to strategically respond to new criteria of the business environment means, in practice, the use of methods, manufacturing and organizational processes, and practices and tools, which mostly have so far been already developed. The available tools and methods are most often used in manufacturing companies for specific tasks, while other tools are under development in order to provide the skills necessary to obtain agility. One of the most important differences between agile and traditional companies is the former's intensive use of integrated information systems (within agility relays) that provide e.g. the best update of data, effective communication, and the wealth of data (Niewiadomski, 2016).

When an agile company "falls into the arms" of a change, it easily and quickly adapts to this change. Therefore, agility will be the company's feature that means an ability to make effective changes in the scope of implemented operations, processes, and business links in response to a constantly changing situation, both in the outside environment and inside the organization.

In agile organizations, in connection with the feature of quick response to the market changes, the intellectual potential of employees gains leading importance. In order to ensure the high operations effectiveness of multidisciplinary project teams, companies employ management techniques oriented toward objectives. The objectives are determined in a way to include the determination of both the quality level and completion time. Management with the use of objectives allows achieving the desired level of flexibility and response to constant changes. In an agile organization, there is a smooth information flow that encourages the integration of individual functional areas. Besides focusing on internal development, agile companies should also intensively seek any market opportunities occurring in the environment. Furthermore, the created early warning systems must be able to recognize threats and identify weaknesses of an organization, allowing it to take the appropriate reaction in time. The reaction may be cooperation with suppliers and even competitors (Lockamy and McCormack, 2004; Kannan et al., 2013).

An agile company bases on three basic factors: the organization and structure of innovative management, authorized employees provided with knowledge, as well as the use of flexible and intelligent technologies. Agility is achieved through the inte- 
gration and development of these three interdependent resources into a single coordinated system. An agile company is built on the following competitive elements: constant change, rapid response, quality improvement, responsibility for employees and the environment, and a comprehensive orientation toward the client. The objectives of creating and developing an agile company are a faster response to different demand patterns, better orientation toward the client and market, a better understanding of client needs, closer relationships with the client, manufacturing flexibility in various production batches, manufacturing flexibility of unique products, manufacturing flexibility of a wide range of products, the ability to quickly respond to new market opportunities, create virtual corporations, and operate under conditions of change, but also a greater inclination to risk.

Among numerous attempts at distinguishing agility from organizational flexibility, there are those that indicate the superiority of agility over flexibility, but also those that combine flexibility and agility (Sajdak, 2013). Despite many common features, characteristic of both concepts, in this article, we separate agility from flexibility in order to verify the strength of the former's impact on business model maturity.

\section{Research Methodology}

Despite emphasizing the importance of flexibility to maintain a long-term competitive advantage, it is difficult to find a clear way of understanding this category in the subject literature. There is a multitude of definitions; there also is a lack of uniformity and even in using the same concept, along with in the various phenomena that are referred to, which consequently leads to many misunderstandings in the interpretation of individual definitions. The situation is hindered by the existence of related terms, such as agility. Moreover, the environment in which a modern company must operate is becoming increasingly complex. People responsible for management are looking for effective indicators that will allow companies to identify areas that require correction by determining the order of improvement actions and by monitoring the effects and sustainability of the implemented business model. In this situation, there arise the following questions. What is the best set of indicators for determining the level of flexibility and agility of a mature production model? What determinants should be evaluated? How to evaluate the results of the improvement activities carried out? Unfortunately, there is no simple and straightforward answer to these questions. There also is no ideal set of desiderata that reflect the ideas behind individual concepts. However, we can set the basic principles that define each of the questions. We can also identify the 
typical indicators worth implementing in most enterprises, which is what we attempt to highlight with this article.

Therefore, recognition was decreed about whether the business model maturity is to be perceived through the prism of agility or flexibility. The conviction of the existence of economic demand for results of practical nature, on the one hand, was our main inspiration to undertake the research and, on the other hand, they became the starting point for formulating eight presumptions based on the study procedure (literature analysis). As the empirical decidability of research hypotheses boils down to their testing (Hajduk, 2011), we abandoned their formulation in this study due to the relatively small research sample. However, based on the identified cognitive gap in the precise identification of constitutive factors of the model's maturity, the existence of an unproven fact was articulated on the basis of other established facts related to it, i.e. presumption. There is currently no consensus among scientists as to the correct ways to verify hypotheses. When formulating our presumptions, we made every effort to ensure that they were clearly formulated, precise, internally consistent, objective, fertile, and scientific (Engelhardt, Kohler and Fürnkranz-Prskawetz, 2009; Wood et al., 2008). From the perspective of the research model structure, presumptions must first be verifiable, i.e. stated in such a way that they can be tested. This required the definition of quantitative methods at the design stage of the research model.

Taking the above into consideration, we prepared the following assumptions:

$\mathbf{P}_{1}$ : Although more and more companies appreciate the business model in which the reference point is the concept of an agile or flexible company, business model maturity is mainly perceived through the prism of agility, identified with the organization's ability to obtain a competitive advantage owing to the intelligent, fast, and proactive use of chances in the environment and appropriate response to threats (Meredith and Francis, 2008).

$\mathbf{P}_{2}$ : The agility and flexibility desiderata of a manufacturing company in the agricultural machinery sector can be prioritized.

$\mathbf{P}_{3}$ : Substantially, the agility defined as the ability to manufacture and effectively offer a wide range of low-cost and high-quality products in a short time period and a full range of sizes - owing to which the company creates value for clients through customization - is a concept aimed at achieving competitive advantage in a dynamic environment. 
$\mathbf{P}_{4}$ : There is a difference between company agility and flexibility; agility is a wider co ncept of analysis.

$\mathbf{P}_{5}$ : A uniform and commonly accepted definition of flexibility and agility has not been created yet.

$\mathbf{P}_{\mathbf{6}}$ : Not all diagnosed desiderata of agility and flexibility are important in the conceptualization of a mature business model. There are factors of both primary and secondary importance.

$\mathbf{P}_{7}$ : The building of flexible company models can base on existing methodological approaches.

$\mathbf{P}_{\mathbf{8}}$ : Flexibility is a derivative of resources available for manufacturers, market expectations, and tasks and operating conditions of organizational managers.

Conducting business under stable macroeconomic conditions creates a possibility for long-term utilization of the developed business concept, whereas in the case of high diversity of ambient conditions (non-linearity), changes in the form of business activities are required. It is important to use a general concept that formulates the logical framework for running a business and its features, such as agility or flexibility. The business model defined in this way is a combination of a company's strategic concept and the technology of its practical implementation, understood as the development of a value chain enabling the efficient operation and renewal of resources and competences.

The conducted deliberations prove the purposefulness of such a method of constructing development strategies that adopt the perspective of market adaptation as its starting point. Let us underline that this is not one of the new management trends but already a necessity dictated by the specificity of highly competitive rules of the agricultural machines market, functioning at almost every level: local, domestic, and international. Therefore, the ability to establish relationships with broadly understood market participants is a recognized vital factor in the continuation and development of entities that operate on the market. A high-quality product - delivered in a short time and in a full range of sizes - is a concept aimed at achieving a competitive advantage in a dynamic environment; hence, the subject matter of this article is perfectly justified, which is confirmed by the empirical argument.

As the efficiency of company operations is determined by the competences associated with creating long-term relationships with the environment - which results from the 
concepts of agility and flexibility - we assume that there is a hierarchy of key desiderata for the business model. There is a possibility of diagnosing a research gap in this area wherein perception can be based on existing methodological approaches; this is the approach we use in this article. When developing a research model, certain principles must be followed that not only justify its creation but also allow one to test the model. Only in this case, while maintaining methodological rigor, research models meet their assumptions and contribute to the enrichment and development of the theory. Therefore, the principles of research model structures and the definition of variables and their dependencies in the form of presented research hypotheses are based on approaches characteristic among studies in management sciences and their scientific explorations. The research implementation diagram is shown in Figure 1.

Figure 1. Research implementation diagram

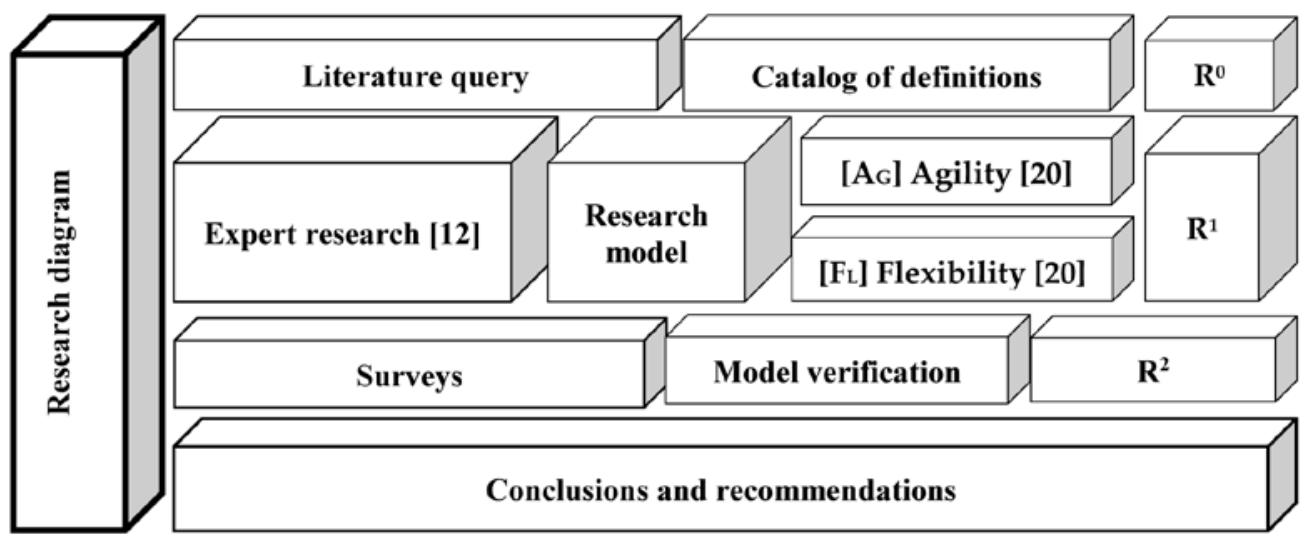

Source: own elaboration.

The implementation of this article's objective and verification of its hypotheses required from us - first and foremost - the creation of a catalog of desiderata that meaningfully identify agility and flexibility. The first research method selected to collect primary data oriented towards the research model development was the reconstruction and interpretation of the subject literature $\left[\mathrm{R}^{0}\right]$ (Slack, 1983; Aaker and Mascarenhas, 1984; Atkinson, 1984; Jones and Ostroy, 1984; Harrigan, 1985; Evans, 1991; Kidd, 1994; Baker, 1996; Adler, Goldoftas and Levine, 1999; Koste and Malhotra, 1999; Yusuf, Sarhadi, and Gunasekaran, 1999; D’Souza and Williams, 2000; Dove, 2001; Sarkis, 2001; Zhang, Vonderembse, and Lim, 2002; Feldman and Pentland, 2003; Bruce, Daly, and Towers, 2004; Bhattacharya, Gibson, and Doty, 2005; Ebben and Johnson, 2005; Avittathur and Swamidass, 2007; Doz and Kosonen, 2008; Hormozi, 2009; Santos Bernardes and Hanna, 2009; Doz and Kosonen, 2010; Eapen, 2010; Trzcieliński, 2011; Urbanowska-Sojkin, 
2013; Weber and Tarba, 2014; Fayezi, Zutshi, and O'Loughlin, 2015; Cegarra-Navarro, Soto-Acosta, and Wensley, 2016; Niewiadomski, 2016; Zhou et al., 2018).

The subject literature review methodology not only allowed for a formalized and objectified synthesis of current scientific achievements or the evaluation of existing research (Columb and Lalkhen, 2005), but above all, it enabled us to identify both explored and unexplored areas (Levy and Ellis, 2006). This gave us the opportunity to frame further research (Gimenez and Tachizawa, 2012), whose results may form the basis for further work and which can be presented in the literature (King and He, 2005; Czakon, 2011). Moreover, at the design level, such an activity allowed us to compile a general catalog of definitions that constitute the basis of the research tool project in the form of an assessment sheet; a preparatory study that determined the conduct of the relevant study.

The process of creating the literature database assumed the application of a mixed approach, i.e. academic literature indexed in scientific databases and the so-called grey literature (Benzies et al., 2006). Extending the process of creating a literature database based on the so-called grey literature was considered important due to the possibility of including the latest scientific publications, publications of a less scientific nature, publications not necessarily peer-reviewed but meeting the requirements of methodological rigor (Conn et al., 2003). Bearing in mind the perceptive and temporal capabilities of researchers, along with the limitation applied in practice, we decided that the final database would include publications that most significantly reflect the discussed definition problem.

In order to verify the accuracy of the selection of individual definitions and to limit their number, we conducted an additional study with the use of brainstorming $\left[\mathrm{R}^{1}\right]$. This method was used to gather information from participants of a meeting about a problem, which is the subject of the study and which was clearly defined by the lecturer. Each participant had the opportunity to express their opinion, which was not evaluated in terms of the information value. Furthermore, there was no rigid framework for conducting discussions, which led to the considerable openness of participants and their expression of opinions. This technique can be used at almost every stage of the management process.

As the identification and analysis of the exposed definitions require prominent experts in the selection methodology of the creative team, we adopted several guidelines. It was assumed that the primary value of expert knowledge would be, first and foremost, basing on so-called best practices, i.e. examples of practical knowledge application (Paulus et al., 1993; Sternberg and Lubart, 1999; Runco, 2004). 
When selecting experts, the key requirements were competences and experience in the area of the study. An expert is a specialist with enough knowledge in each field. When creating the group of experts, the condition was met, namely: "a group must be able to solve the studied problem reliably and efficiently." In the context of the above, the selected management practitioners were experts (Table 1). The experts were selected based on such qualities as competence, creativity (ability to solve creative tasks), attitude to expertise, conformism, constructive thinking, and self-criticism. Competence expresses the expert's level of qualification in each field. It was determined based on an expert's creative analysis, knowledge of the field, and understanding of problems. Expert competence was assessed based on the competence coefficient, which expressed the dependence of the informativity coefficient [Ki] (knowledge of the given issue) and argumentation coefficient [KA].

Table 1. Characteristics of experts

\begin{tabular}{|c|c|c|c|c|c|c|c|c|c|c|c|c|c|c|c|c|c|c|c|c|c|}
\hline$E$ & \multicolumn{5}{|c|}{ Age } & \multicolumn{3}{|c|}{ Education } & \multicolumn{4}{|c|}{$\begin{array}{l}\text { Company } \\
\text { size }\end{array}$} & \multicolumn{4}{|c|}{$\begin{array}{l}\text { Production } \\
\text { nature }\end{array}$} & \multicolumn{3}{|c|}{$\begin{array}{l}\text { Business } \\
\text { activity form }\end{array}$} & \multicolumn{2}{|c|}{$\begin{array}{c}\text { Manufacturing } \\
\text { process }\end{array}$} \\
\hline $\begin{array}{l}\mathbf{P} \\
\mathbf{E} \\
\mathbf{R} \\
\mathbf{T}\end{array}$ & 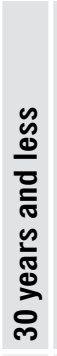 & 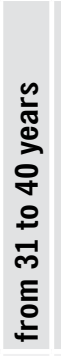 & 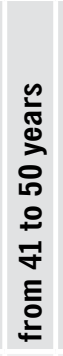 & 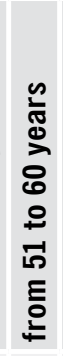 & $\begin{array}{l}0 \\
0 \\
\frac{0}{0}\end{array}$ & 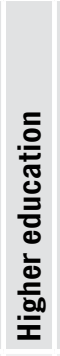 & 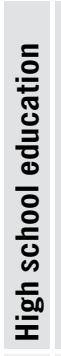 & 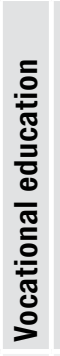 & $\begin{array}{l}\frac{0}{\mathrm{U}} \\
\frac{0}{\Sigma}\end{array}$ & $\begin{array}{l}\overline{\bar{N}} \\
\bar{E}\end{array}$ & 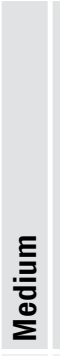 & : & 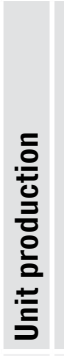 & 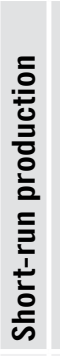 & 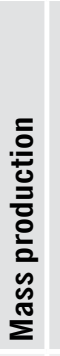 & 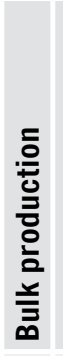 & 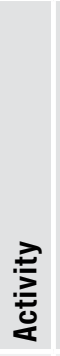 & 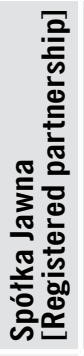 & 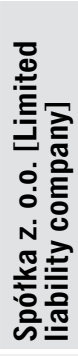 & 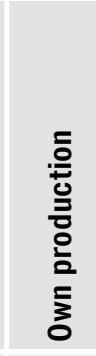 & 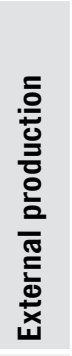 \\
\hline B.K & & & & & $x$ & & & $x$ & & & $x$ & & $x$ & $x$ & $x$ & & & $x$ & & $x$ & \\
\hline T.P & & & & & $x$ & & $x$ & & & & $x$ & & & $x$ & & $x$ & & & $x$ & $x$ & \\
\hline G.W. & & & & & $x$ & $X$ & & & & $x$ & & & & $x$ & & & $x$ & & & $x$ & \\
\hline H.K. & & & & $X$ & & $x$ & & & & & $X$ & & $x$ & $x$ & & & $x$ & & & $x$ & \\
\hline B.P. & & $x$ & & & & $x$ & & & & & $x$ & & $X$ & $X$ & & $X$ & & & $x$ & $X$ & \\
\hline I.K. & & & $X$ & & & $X$ & & & & & $x$ & & & $X$ & $X$ & & & $X$ & & $X$ & \\
\hline T.K. & & $x$ & & & & $x$ & & & & & $x$ & & $x$ & $X$ & & & $x$ & & & $x$ & \\
\hline M.S. & & & & $X$ & & & $X$ & & & & $x$ & & & & $X$ & & $x$ & & & $X$ & $x$ \\
\hline A.S. & & & & & $x$ & & $X$ & & & & & $X$ & & & & $X$ & & & $x$ & $X$ & $x$ \\
\hline P.N. & & & $X$ & & & $X$ & & & & $X$ & & & $X$ & $X$ & & & $x$ & & & $X$ & $x$ \\
\hline D.W. & & & & $x$ & & & & $X$ & & $x$ & & & $X$ & $X$ & & & $X$ & & & $X$ & $X$ \\
\hline P.L. & & & $x$ & & & $x$ & & & & & & $X$ & & & $X$ & & & & $X$ & & $X$ \\
\hline
\end{tabular}

Source: own elaboration. 
In order to ensure the adequacy of expert assessments, a representative number of experts was selected and methodologically questioned. As the precision of decisions and assessments made by a small group of experts may be considered just as credible as the evaluation of a large group, only 17 people were invited to the survey; the high level of expert knowledge would have allowed us to reduce their number even to five.

The analysis of companies' features structure represented by the experts shows that these are companies based solely on the Polish capital. Half of the companies participating in the study are organized in the form of a limited liability company, a limited partnership (33.33\%), or a registered partnership (16.67\%). Half of the respondents were individuals conducting business activities. Considering the distribution due to the prevailing nature of production, the represented businesses practiced mass production (four companies), bulk production (three companies), short-run production (nine companies), or unit production (six companies). In the case of five companies, the production mainly involved the assembly of components - purchased from external suppliers - to finished products, while 11 companies practiced production processes that included several phases, in which components and finished products were consecutively produced.

Let us observe the profile of experts characteristics. The experts were owners and managers representing small (three persons; 25\%), medium (seven persons; 58.33\%), and large (two persons; 16.67\%) companies.

In terms of age, $16.67 \%$ of experts were in the age range of $31-40$ years, $25 \%$ in the age range of $41-50$ years, $25 \%$ in the range of $51-60$ years, while $33.33 \%$ of the surveyed experts were over 60 years old.

We assumed that the discussion in a group of such selected experts might lead to the creation of new definitions and the verification of the selection accuracy of definitions developed based on the literature analysis. The qualitative research, based on experience and expert knowledge, allowed for identifying opinions, associations, and connections similar to existing ones. Moreover, the experts provided interesting information on the language that "industry experts" use to describe the phenomena constituting the subject matter of the research. We believe that it allowed us to avoid mistakes at the level of research model construction.

In order to implement the research, a coordinator was tasked with organizing the resources necessary to implement the project. At this stage, it was important to appoint a team of creative thinkers and provide the project with sustainability until the 
moment of selected ideas implementation, but also to prepare and disseminate information on the research among interested persons.

The study distinguishes two stages: at the first stage, the coordinator presented a catalog of definitions that resulted from the subject literature reconstruction and interpretation. However, at the second stage, we hosted a session of generating original concepts in teams of three, based on indicated definitions. For 25 minutes, the participants intensively indicated (important in their opinion) definitions of agility and flexibility that determine business model maturity. After the end of the session, we assessed the obtained results. The research coordinators wrote down all the mentioned definitions and compared them with the selected researchers' proposals. Moreover, they grouped similar ideas that, in retrospect, allowed them to determine the final list, which in the further part of the article was verified with deliberately selected representatives of the agricultural machinery sector companies.

The proposed assessment concept (Figure 2) included 40 characteristics, including flexibility (20) and agility (20).

Figure 2. Assessment areas: business model maturity context

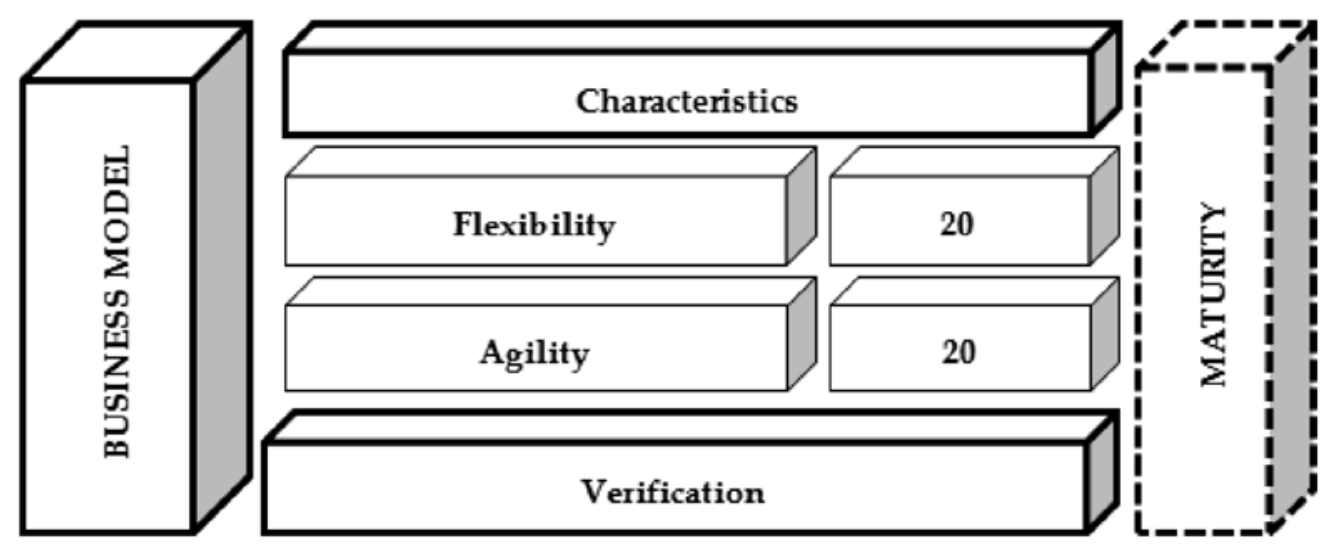

Source: own elaboration.

The primary stage of the research was implemented on September 19-22, 2019. The research was conducted during direct meetings organized within the framework of the $11^{\text {th }}$ AGRO SHOW 2019 International Agricultural Fair in Bednary near Poznań (Pobiedziska municipality). The study covered a total of 91 companies, which means that $82.73 \%$ of invited companies took part in the study. The verification of representativeness of the study in terms of the distribution of the entire surveyed population 
and the population of the study performed with the use of a chi-squared test allowed us to conclude that the compared structures - i.e. the population structure of the studied and implemented test - are consistent.

When deciding on the choice of companies, the key criterion was researchers' direct acquaintances; among other links, cooperation with Fortschritt Poland and the Industrial Institute of Agricultural Engineering - Łukasiewicz Research Network. This allowed us to determine whether a respondent may be interested in expressing his/her views, and if $\mathrm{s} / \mathrm{he}$ has sufficient knowledge and experience in the scope of the issue. The application of a deliberate selection technique and the possibility of conducting most of the studies (68.13\%) during the Forum of Agricultural Machine Dealers held on September 19, 2019, undoubtedly affected their quality, the return of questionnaires, and the reliability of answers. Moreover, in order to obtain greater representativeness of the studied target group and as many responses as possible on September 20-22, 2019, we conducted further studies among deliberately selected companies (31.87\%).

The results were interpreted based on respondents' declarations. The respondents were asked to assess the adequacy (coherence) of presented definitions for company orientation and its business modeling direction. For this purpose, a five-grade scale was applied, in which one meant a very low correlation of the definition with the adopted business model and five - very high.

The respondents were owners and managers representing micro (11; 12.09\%), small (23; 25.27\%), medium (48; 52.75\%), and large (nine; 9.89\%) manufacturing companies operating in the agricultural machinery sector. In the case of large companies, $77.78 \%$ declared a foreign capital share. The study was attended by manufacturers of tractors, combine harvesters, trailers, combined cultivators, seeders, silos, forklifts, and any equipment used in agriculture. The detailed data are shown in Table 2. The research involved the participation of 39 owners ( $42.86 \%$ of all the surveyed) and 52 managers (57.14\% of all the surveyed).

Among the respondents, a group of people between 41 and 50 years old (47.25\%) was dominant; only $3.30 \%$ constituted the surveyed in the age range up to 30 years, the age of $26.27 \%$ of the surveyed was between 31 and 40 years old, $16.48 \%$ was from 51 to 60 years old, and six persons were over 60 years old). Regarding owners, $41.02 \%$ of all owners were over 50 years old, the age of $46.15 \%$ of all owners was in the range from 41 to 50 years, while $12.82 \%$ of all owners were under 40 years. In the case of managers, $9.62 \%$ of the surveyed were over 50 years, the age of $48.08 \%$ was in the range of 
$41-50$ years, and $36.54 \%$ of all managers were between 31 and 40 years, while $5.77 \%$ was under 30 years.

Table 2. Characteristics of the studied population by age $(\mathrm{N}=91)$

\begin{tabular}{|c|c|c|c|c|c|c|}
\hline \multirow{4}{*}{ Range } & \multicolumn{6}{|c|}{ Age } \\
\hline & \multicolumn{2}{|c|}{ Owners (39) } & \multicolumn{2}{|c|}{ Managers (52) } & \multicolumn{2}{|c|}{ Total (91) } \\
\hline & \multicolumn{2}{|c|}{$42.86 \%$} & \multicolumn{2}{|c|}{$57.14 \%$} & \multicolumn{2}{|c|}{$100 \%$} \\
\hline & $\begin{array}{c}\text { Number of } \\
\text { participants }\end{array}$ & $\%$ & $\begin{array}{c}\text { Number of } \\
\text { participants }\end{array}$ & $\%$ & $\begin{array}{c}\text { Number of } \\
\text { participants }\end{array}$ & $\%$ \\
\hline to 30 years & $\mathrm{N}=0$ & 0.00 & $N=3$ & 5.77 & $N=3$ & 3.30 \\
\hline from 31 to 40 years & $\mathrm{N}=5$ & 12.82 & $\mathrm{~N}=19$ & 36.54 & $\mathrm{~N}=24$ & 26.37 \\
\hline from 41 to 50 years & $\mathrm{N}=18$ & 46.15 & $\mathrm{~N}=25$ & 48.08 & $\mathrm{~N}=43$ & 47.25 \\
\hline from 51 to 60 years & $\mathrm{N}=10$ & 25.64 & $\mathrm{~N}=5$ & 9.62 & $\mathrm{~N}=15$ & 16.48 \\
\hline over 60 & $\mathrm{~N}=6$ & 15.38 & $\mathrm{~N}=0$ & 0.00 & $N=6$ & 6.59 \\
\hline In total: & $N=39$ & 100.00 & $\mathrm{~N}=\mathbf{2 7}$ & 100.00 & $\mathrm{~N}=91$ & 100.00 \\
\hline
\end{tabular}

Source: own elaboration.

Among the surveyed, the group of persons with high school or higher education was the largest: (91.21\%), 58.97\% of whom had higher education, $28.21 \%$ - high school education, and $12.82 \%$ - vocational education. In the case of managers, $69.23 \%$ had higher education, $25.00 \%$ had high school education, and 5.77\% had vocational education. The detailed characteristics are shown in Table 3.

The recognition was made on the basis of the average value calculated under the indications of respondents; a common practice used in the development of the survey results. Statistical measurement methods and statistical inference were used to validate the results. Collecting and developing research results required deductive and reductive reasoning, analogy reasoning, and elements of comparative analysis methods. The operationalization of the factors of flexibility and agility (a set of key desiderata) was performed on the basis of the main assumptions of the expert method. Due to some differences in the applied measurement scales, we had to employ different methods of data analysis. All calculations, including charts, were made in IBM SPSS STATISTICS and MS Excel. 
Table 3. Characteristics of the studied population by education $(\mathrm{N}=91)$

\begin{tabular}{|c|c|c|c|c|c|c|}
\hline \multirow{4}{*}{ Range } & \multicolumn{6}{|c|}{ Education } \\
\hline & \multirow{2}{*}{\multicolumn{2}{|c|}{$\begin{array}{c}\text { Owners (39) } \\
57.14 \%\end{array}$}} & \multirow{2}{*}{\multicolumn{2}{|c|}{$\begin{array}{c}\text { Managers (52) } \\
42.86 \%\end{array}$}} & \multirow{2}{*}{\multicolumn{2}{|c|}{$\begin{array}{c}\text { Total (91) } \\
100 \%\end{array}$}} \\
\hline & & & & & & \\
\hline & $\begin{array}{c}\text { Number of } \\
\text { participants }\end{array}$ & $\%$ & $\begin{array}{l}\text { Number of } \\
\text { participants }\end{array}$ & $\%$ & $\begin{array}{c}\text { Number of } \\
\text { participants }\end{array}$ & $\%$ \\
\hline $\begin{array}{l}\text { Primary } \\
\text { education }\end{array}$ & $\mathrm{N}=0$ & 0.00 & $\mathrm{~N}=0$ & 0.00 & $\mathrm{~N}=0$ & 0.00 \\
\hline $\begin{array}{l}\text { Vocational } \\
\text { education }\end{array}$ & $\mathrm{N}=5$ & 12.82 & $\mathrm{~N}=3$ & 5.77 & $\mathrm{~N}=8$ & 8.79 \\
\hline $\begin{array}{l}\text { High school } \\
\text { education }\end{array}$ & $\mathrm{N}=11$ & 28.21 & $\mathrm{~N}=13$ & 25.00 & $N=24$ & 26.37 \\
\hline Higher education & $\mathrm{N}=23$ & 58.97 & $N=36$ & 69.23 & $\mathrm{~N}=59$ & 64.84 \\
\hline In total: & $N=39$ & 100.00 & $N=52$ & 100.00 & $N=91$ & 100.00 \\
\hline
\end{tabular}

Source: own study.

In the course of conducted studies, we attempted to interpret the results and conduct a more thorough analysis based on respondents' declarations. From this viewpoint, it was important to correctly prepare the obtained primary data and its proper arrangement. Such a data processing method made it possible to sort the material and reject insignificant, unreliable, or at least questionable data. The important stage was a description of the obtained data and its interpretation, as emphasized below.

\section{Own Study Results}

Considering the correlation criterion of the referred definitions related to flexibility (20) and agility (20), we divided them into three groups, i.e. definitions characterized by high, medium, and low interdependence with the business model. The assignment of separated definitions to specific groups was made on the basis of their average value calculated under the indication of the total number of respondents participating in the survey. We adopted the following solution: the lower limit of the range of values for a group of definitions with a high interdependence level was comprised of the third quartile value, while the upper limit of the range of values for the definition with low interdependence was based upon the first quartile value. This resulted in the following value ranges: 
- 5.00-3.50 - (group 1) definitions of high interdependence/relationship,

- 3.49-2.50 - (group 2) definitions of average interdependence/relationship,

- 2.49 and less - (group 3) definitions of low interdependence/relationship.

Table 4. Definitions of high interdependence/relationship: own study results

\begin{tabular}{|c|c|c|c|c|c|c|c|c|}
\hline \multirow{3}{*}{ Item } & \multirow{3}{*}{$F_{L} / A_{G}$} & \multirow{3}{*}{ DEFINITION AUTHOR } & \multicolumn{5}{|c|}{ \% OF INDICATIONS } & \multirow{3}{*}{$\bar{x}$} \\
\hline & & & \multicolumn{5}{|c|}{ FEATURE VALUE } & \\
\hline & & & 1 & 2 & 3 & 4 & 5 & \\
\hline \multirow{2}{*}{1.} & \multirow{2}{*}{$A_{G}$} & \multirow{2}{*}{ Teece } & 1.0 & 2.0 & 3.0 & 20.0 & 65.0 & \multirow{2}{*}{4.60} \\
\hline & & & 1.1 & 2.2 & 3.3 & 22.0 & 71.4 & \\
\hline \multirow{2}{*}{2.} & \multirow{2}{*}{$\mathrm{F}_{\mathrm{L}}$} & \multirow{2}{*}{ Olagher } & 1.0 & 2.0 & 3.0 & 23.0 & 62.0 & \multirow{2}{*}{4.57} \\
\hline & & & 1.1 & 2.2 & 3.3 & 25.3 & 68.1 & \\
\hline \multirow{2}{*}{3.} & \multirow{2}{*}{$\mathrm{F}_{\mathrm{L}}$} & \multirow{2}{*}{ De Tonie, Tonchi } & 1.0 & 2.0 & 5.0 & 22.0 & 61.0 & \multirow{2}{*}{4.54} \\
\hline & & & 1.1 & 2.2 & 5.5 & 24.2 & 67.0 & \\
\hline \multirow{2}{*}{4.} & \multirow{2}{*}{$A_{G}$} & \multirow{2}{*}{ Gunasekaran } & 1.0 & 2.0 & 7.0 & 21.0 & 60.0 & \multirow{2}{*}{4.51} \\
\hline & & & 1.1 & 2.2 & 7.7 & 23.1 & 65.9 & \\
\hline \multirow{2}{*}{5.} & \multirow{2}{*}{$A_{G}$} & \multirow{2}{*}{ Vokurka, Fliedner } & - & 2.0 & 5.0 & 30.0 & 54.0 & \multirow{2}{*}{4.49} \\
\hline & & & - & 2.2 & 5.5 & 33.0 & 59.3 & \\
\hline \multirow{2}{*}{6.} & \multirow{2}{*}{$\mathrm{F}_{\mathrm{L}}$} & \multirow{2}{*}{ Nogalski, Niewiadomski } & 1.0 & 2.0 & 5.0 & 31.0 & 52.0 & \multirow{2}{*}{4.44} \\
\hline & & & 1.1 & 2.2 & 5.5 & 34.1 & 57.1 & \\
\hline \multirow{2}{*}{7.} & \multirow{2}{*}{$A_{G}$} & & 1.0 & 1.0 & 7.0 & 38.0 & 44.0 & \\
\hline & & D AvenI & 1.1 & 1.1 & 7.7 & 41.8 & 48.4 & 4.35 \\
\hline 8 & $\mathrm{~F}$ & Ochert_Pociecha & 1.0 & 3.0 & 8.0 & 33.0 & 46.0 & 432 \\
\hline 0. & $\mathrm{~T}_{\mathrm{L}}$ & 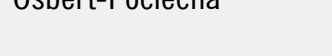 & 1.1 & 3.3 & 8.8 & 36.3 & 50.5 & 4.02 \\
\hline 0 & & Uluhonnucle Coikin & - & 1.0 & 13.0 & 38.0 & 39.0 & 26 \\
\hline 9. & $A_{G}$ & Uivaniowska-sojkIII & - & 1.1 & 14.3 & 41.8 & 42.9 & $4 . \angle 0$ \\
\hline 10 & & & - & 4.0 & 13.0 & 33.0 & 41.0 & \\
\hline 10. & $A_{G}$ & Snariti, Lnang & - & 4.4 & 14.3 & 36.3 & 45.1 & 4.2Z \\
\hline & & Kasiewicz, Ormińska. & - & 2.0 & 16.0 & 36.0 & 37.0 & \\
\hline 11. & $\mathrm{r}_{\mathrm{L}}$ & Rogowski, Urban & - & 2.2 & 17.6 & 39.6 & 40.7 & 4.19 \\
\hline
\end{tabular}




\begin{tabular}{|c|c|c|c|c|c|c|c|c|}
\hline \multirow{2}{*}{12.} & \multirow{2}{*}{$\mathrm{F}_{\mathrm{L}}$} & \multirow{2}{*}{ Trzcieliński } & - & 2.0 & 15.0 & 39.0 & 35.0 & \multirow{2}{*}{4.18} \\
\hline & & & - & 2.2 & 16.5 & 42.9 & 38.5 & \\
\hline \multirow{2}{*}{13.} & \multirow{2}{*}{$\mathrm{F}_{\mathrm{L}}$} & \multirow{2}{*}{ Stabryła } & 1.0 & 4.0 & 18.0 & 29.0 & 39.0 & \multirow{2}{*}{4.11} \\
\hline & & & 1.1 & 4.4 & 19.8 & 31.9 & 42.9 & \\
\hline \multirow{2}{*}{14.} & \multirow{2}{*}{$\mathrm{F}_{\mathrm{L}}$} & \multirow{2}{*}{ Bahrami } & 1.0 & 3.0 & 20.0 & 31.0 & 36.0 & \multirow{2}{*}{4.08} \\
\hline & & & 1.1 & 3.3 & 22.0 & 34.1 & 39.6 & \\
\hline \multirow{2}{*}{15.} & \multirow{2}{*}{$A_{G}$} & \multirow{2}{*}{ Nogalski, Niewiadomski } & 1.0 & 4.0 & 21.0 & 29.0 & 36.0 & \multirow{2}{*}{4.04} \\
\hline & & & 1.1 & 4.4 & 23.1 & 31.9 & 39.6 & \\
\hline \multirow{2}{*}{16.} & \multirow{2}{*}{$A_{G}$} & \multirow{2}{*}{ Meredith, Francis } & 1.0 & 4.0 & 19.0 & 36.0 & 31.0 & \multirow{2}{*}{4.01} \\
\hline & & & 1.1 & 4.4 & 20.9 & 39.6 & 34.1 & \\
\hline \multirow{2}{*}{17.} & \multirow{2}{*}{$A_{G}$} & \multirow{2}{*}{ Sajdak } & 2.0 & 5.0 & 16.0 & 40.0 & 28.0 & \multirow{2}{*}{3.96} \\
\hline & & & 2.2 & 5.5 & 17.6 & 44.0 & 30.8 & \\
\hline \multirow{2}{*}{18.} & \multirow{2}{*}{$A_{G}$} & \multirow{2}{*}{ Roberts, Grover } & 2.0 & 7.0 & 17.0 & 39.0 & 26.0 & \multirow{2}{*}{3.88} \\
\hline & & & 2.2 & 7.7 & 18.7 & 42.9 & 28.6 & \\
\hline \multirow{2}{*}{19.} & \multirow{2}{*}{$A_{G}$} & & 3.0 & 5.0 & 29.0 & 24.0 & 30.0 & \\
\hline & & Gunasekaran & 3.3 & 5.5 & 31.9 & 26.4 & 33.0 & 3.80 \\
\hline & & & 4.0 & 6.0 & 25.0 & 32.0 & 24.0 & \\
\hline 0. & $\Gamma_{\mathrm{L}}$ & Evalis & 4.4 & 6.6 & 27.5 & 35.2 & 26.4 & 3.13 \\
\hline & & & 3.0 & 6.0 & 29.0 & 30.0 & 23.0 & \\
\hline 1. & $A_{G}$ & Golumall & 3.3 & 6.6 & 31.9 & 33.0 & 25.3 & 3.10 \\
\hline & $A$ & Trzciolińcki & 4.0 & 7.0 & 26.0 & 30.0 & 24.0 & 369 \\
\hline & $A_{G}$ & IILCIEIIISKI & 4.4 & 7.7 & 28.6 & 33.0 & 26.4 & 3.09 \\
\hline & & & 4.0 & 7.0 & 26.0 & 32.0 & 22.0 & \\
\hline$\angle 3$. & $A_{G}$ & numlar, IVIotwanti & 4.4 & 7.7 & 28.6 & 35.2 & 24.2 & 3.07 \\
\hline & & Dahmaradeh & 4.0 & 8.0 & 25.0 & 33.0 & 21.0 & \\
\hline 4. & $A_{G}$ & and Banihashemi & 4.4 & 8.8 & 27.5 & 36.3 & 23.1 & 3.65 \\
\hline & & Prillmon & 3.0 & 9.0 & 29.0 & 30.0 & 20.0 & 260 \\
\hline J. & $r_{L}$ & DIIIIIवा & 3.3 & 9.9 & 31.9 & 33.0 & 22.0 & 0.00 \\
\hline & $F_{1}$ & Ancoff & 3.0 & 7.0 & 30.0 & 36.0 & 15.0 & 358 \\
\hline & $\mathrm{TL}$ & 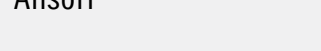 & 3.3 & 7.7 & 33.0 & 39.6 & 16.5 & 0.00 \\
\hline
\end{tabular}

Source: own elaboration based on Niewiadomski (2016), Trzcieliński (2011), Baker (1996), Sajdak (2013). 
The business model is most commonly identified by its ability to reconfigure available skills through sensing and creating opportunities and threats and the use of market opportunities. In such an approach, it affects competitiveness by improving, connecting, and reconfiguring tangible and intangible assets (the average rating of 4.60; 71.4\% of indications for the assessment of five points). The business model is also characterized by the ability to introduce new products, new resources, and new production methods, along with the ability to integrate them with existing production systems (the average rating of 4.57; 68.1 of indications for the assessment of five points).

The effective functioning of manufacturing companies depends on the proper organization of the system of elements and relationships between them, together with the process of transformation of an input vector into an output vector. Hence, what determines the manufacturer's competitiveness is a deliberately designed and organized material, information, and energy system operated by a human and involved in manufacturing goods that meet the client's needs. This is the methodology of building a production system model that inaugurates the determination of goods that will be manufactured. On this basis, what is created is the management strategy, along with the internal and external environment analysis of the manufacturing structure. In the context of the above, in the opinion of the studied companies, the business model is reflected by the production system's capability of response to changes, while incurring low outlays from the perspective of time, costs, or results of the activity (the average rating of 4.54; $67.0 \%$ of indications for the assessment of five points). An important element contributing to the organizational effectiveness of the proposed business model - also in the long run - is to obtain and maintain a competitive advantage, which includes innovations in the manufacturing process alongside the application of information and communication technologies that require company reorganization and the adaptation of new marketing strategies (the average rating of $4.51 ; 65.9 \%$ of indications for the assessment of five points).

The observation of economic practice evidenced that the modern company is clientoriented, and it is able and willing to cooperate with internal and external environments which, in turn, is reflected by the high level of communication skills and readiness to adopt changes and reconfigurations of existing activities. In the context of the business model oriented in such a manner, what is important is the ability to manufacture and effectively offer a wide range of low-cost and high-quality products in a short time period and in a full range of sizes, owing to which a company creates value for clients through customization (the average rating of 4.49; 59.3\% of indications for the assessment of five points). 
The business formation process, in the opinion of the studied companies, is based on company resources. The resource-based approach assumes that the company should use arising opportunities. In this approach, unique held resources allow for the use of arising strategies, enabled by a system of interrelated technological, relational, and financial resources and knowledge, the ability to use them, but also the acquired experience, adopted models, values and attitudes oriented toward efficient, and the effective implementation of new products (quicker than competitors) in a constantly changing environment, created under the influence of the moment of market needs (the average rating of $4.44 ; 57.1 \%$ of indications for the assessment of five points). Attention is drawn to the ability to use the emerging opportunities as incentives to proffer innovative market solutions and apply these in the process of competing in the market through the allocation of necessary resources, knowledge, and market relationships in a manner that is rapid and surprising for competitors (the average rating of $4.35 ; 48.4 \%$ of indications for the assessment of five points).

Companies' modern functioning conditions are not unique, but they are different from those of the past, both in a negative and positive way. On the one hand, companies face increasingly faster changes and complex problems but, on the other hand, owing to the appropriate agility level, this situation may be an opportunity for companies to develop; especially if they can solve occurring problems faster and more efficiently than their competitors. The above considerations allow us to conclude that the basis for effective management is the concentration on the outlook for emerging changes, responding to them, and developing these skills from the perspective of occurring business opportunities. Therefore, without prejudice to organizational coherence limits that ensure the achievement of its synergistic effect, what becomes the key desideratum of the business model postulated by the studied companies is the ability to make changes under the influence of internal or external impulses in such a way as to create the conditions to compete on the market and realize selected efficiency objectives (the average rating of 4.32; $50.5 \%$ of indications for the assessment of five points). Since changes always accompany economic reality, modern business models are based on:

- the ability to function in the constantly changing and unpredictable business environment (the average rating of $4.26 ; 42.9 \%$ of indications for the assessment of five points);

- the ability to deal with unexpected challenges, overcome unprecedented threats, and use emerging business opportunities (the average rating of 4.22; $45.1 \%$ of all indications for the assessment of five points);

- entity property that concerns its vulnerability to changes - under the influence of specific factors - that is, the particular ease and the rate of response to them 
with the related ability to make appropriate changes (average rating of 4.19; $40.7 \%$ of all indications for the assessment of five points).

Regardless of the fact whether these activities respond to changes occurring in the environment or they result from other circumstances, the business model base is the ability to expand the repertoire of activities (the average rating of 4.18 ; 38.5\% of all indications for the assessment of five points). Therefore, the studied companies declare the possibility of transforming their structures or system properties, at which the stationary or dynamic equilibrium is maintained or obtained (the average rating of 4.11; $42.9 \%$ of all indications for the assessment of five points). The important features of the environment in which modern companies operate are openness, complexity, and a high level of turbulence. From the viewpoint of the surveyed manufacturers, it is more beneficial to operate in an unstable environment, as this creates an opportunity to showcase the talents and creativity of employees, including the ability to identify future events. As systems of events and processes are so complicated that it is impossible to describe them precisely, the business basis of studied companies is the ability to continuously respond to unpredictable changes and their ability to adapt to unexpected consequences of forecasted changes (the average rating of 4.08 ; $39.6 \%$ of all indications for the assessment of five points).

In the literature, there is quite a large variety in terms of defining the business model. However, most definitions emphasize the ability to build relationships with clients. The common denominator of the quoted definitions is the ability to create value. The creation, development, and maintenance of a resource that reflects this ability and includes all the elements affecting the perception of the company and its relationships with clients require careful planning and the consistent implementation of the outlined business model, which reflects:

- faster response to differentiated demand patterns;

- more effective orientation toward clients and market;

- a better understanding of client needs through closer relationships with the client;

- production flexibility in various production batches;

- the production flexibility of unique products;

- the production flexibility of a wide range of products;

- the ability to quickly react to new market opportunities, create virtual corporations, and operate under conditions of change;

- greater vulnerability to risk (the average rating of 4.04, 39.6\% of indications for the assessment of five points). 
The central assumption in the presented approach is the original proposal of the value offered to clients reflected by meeting specific requirements of clients; in contrast to the mass production process, in which the production was for an "average" client (the average rating of $4.01 ; 34.1 \%$ of indications for the assessment of five points).

As a result of the effective value provided to clients, client capital is created. This process should be based on an in-depth understanding of needs, objectives, and sources of clients' values. Declarations made by companies in this scope prove that the ability to adapt the offer and level of service to clients' expectations is at a relatively high level. Managers declare their companies' capability of preparing the offer that enables them to meet the changing requirements of individual clients (the average rating of 3.96; $30.8 \%$ of all indications for the assessment of five points) and the capability of meeting the client's needs and a quick response (the average rating of $3.88 ; 28.6 \%$ of all indications for the assessment of five points).

Modern companies focus on searching for effective business models, decisions, and instruments of company management relevant in given circumstances, by implication leading to the achievement of success which, in turn, ensures the entity's existence on the market. Undertaking survival issues in management and quality sciences may result in several reflections. It is possible to wonder whether company survival should be treated as a company's business activity objectives or if it is simply a necessary condition to ensure that the company can implement the economic or social objectives. Regardless, the necessary conditions for the company's stay on the market in a longer time period include its competitiveness, innovativeness, and related financial liquidity. From this perspective, it is crucial to introduce technical progress and to achieve the market advantage on the basis of tangible and intangible assets owned by the company, efficient knowledge management, and the ability to cope in an environment full of unpredictable changes that require a quick and effective response to required changes (the average rating of $3.80 ; 33.0 \%$ of indications for the assessment of five points).

In the context of the business model outlined in such a way, attention is drawn to avoidance and the removal of competitor-based threats, which is guaranteed by the capability of adaptation, mobility, modification, improvement, dexterity, agility, smoothness, plasticity, resilience, etc. Each of these dimensions reacts to the threat resulting from changes mainly in the external environment of the organization or becomes a "pressure" on this environment (the average rating of $3.73 ; 26.4 \%$ of all indications for the assessment of five points). 
The business model can be understood as activities that the company carries out using the resources to create the highest value for the client. The primacy of creating values results from perceiving it as the company's most important objective, the achievement of which gives it a business advantage. Its most important financial dimension is profitability, on the level of which the company's activities and its resources have a significant impact. The studied companies hold similar views on the approach to the business model. This is illustrated by the complex response to business challenges related to achieving profitability in dynamically changing global markets, characterized by high quality, efficiency, and the personalization of goods and services (the average rating of 3.70; $25.3 \%$ of all indications for the assessment of five points).

The scope of activities in a manufacturing company's business model refers to its products and services. Companies relatively often expand or narrow the scope of their activities. The key issue in designing the business model is to determine the necessary changes, considering the client's perspective, while allowing for the generation of high profit and providing for the strategic control of generated costs. The implementation of these elements, on the one hand, lies in the application of concepts and methods appropriate for lean enterprises, and on the other hand, it lies in the use of various management models and methods, which in perspective reflects the ability to utilize created market opportunities (the average rating of $3.69 ; 26.4 \%$ of all indications for the assessment of five points).

Changes in the environment prove that there is a need to adapt companies to the unpredictable and rapidly changing conditions of their functioning. Therefore, companies mobilize managers to develop competences in crisis management, search for the most effective methods for overcoming crisis situations, constantly update knowledge of the causes of their emergence, create early warning systems, and develop corrective strategies. The readiness of companies for periodic organizational changes allows them to continue regardless of the situation in which they happen to find themselves at any one time. The time of success is the best moment to make changes. This theoretical recommendation should be reflected in practical activities, which can be seen in the case of business modeling among the studied companies, wherein we notice the ability to accelerate activities in a critical situation, starting from identifying market needs and ending with the delivery of a finished product to the client (the average rating of $3.67 ; 24.2 \%$ of all indications for the assessment of five points).

In the business models created by the studied companies, there is social responsibility oriented toward permanent and long-term action for the environment. An important manifestation of this approach is the understanding that a company must act with 
respect for its employees. This primarily bases on partnership and the mutual satisfaction of employees and employers. Herein, only a holistic approach to the cooperation model, the knowledge of needs and preferences, but also adapting the offer to the prevailing standards can contribute to success and mutual benefits. Thus, companies respond appropriately to changes in their economic environment owing to the acquired skills and the understanding of the idea of social responsibility of their modeled businesses (the average rating of $3.65 ; 21.0 \%$ of all indications for the assessment of five points).

A company's technical culture is closely associated with the adopted business model and the company's human resources. The creation of a set of standards, rules, or expected behaviors requires the precision and refinement of every detail by managers. All these elements are analyzed inside the company so that they can later be reflected in the image and relationships with a group of stakeholders. It is easier for companies to implement all objectives and assumptions if positive relationships exist. Therefore, they become more competitive and better perceived by their internal and external environment. This contributes to the ability to quickly adapt to changing client needs and competitive requirements (the average rating of $3.60 ; 22.0 \%$ of all indications for the assessment of five points).

Since economic practice as a remedy to increase environmental unpredictability most often chooses the resource orientation, we deem it reasonable to treat resources in the business model category. This is especially so in that the issues related to company resource liquidity are one of the key issues, always valid for each generation unit. Retaining this liquidity, both in the short and long term, is undoubtedly one of the most important elements in the functioning of every company, while the effective management of resource liquidity is a necessary condition for its development. Resource liquidity guarantees that a company can cope with changes in the environment. Instead of influencing them, an organization tries to respond to them (the average rating of $3.58 ; 16.5 \%$ of all indications for the assessment of five points). Such a business model was emphasized in the course of our studies.

As part of the assessment made based on 40 ordered desiderata, a total of 26 definitions (65\%) qualified to the group with high interdependence with the business model. In such a system, the conducted studies allow us to state that business models are seen rather from the perspective of the strategic ability of companies to allow for the quick adaptation to unforeseen and sudden changes on the market (57.69\%) and less often as a multidimensional concept of maintaining a balance between extremes related to making changes (42.31\%). 
The situation is different if we assume that key definitions will be set by a subset constituting $20 \%$ of the entire set of definitions (Pareto 20/80). Assuming that $20 \%$ of elements of any collectivity represents $80 \%$ of the cumulative value of the feature, due to which a given collectivity is analyzed, there appears balance between the business model maturity perception through the prism of agility and flexibility (50/50).

In practice, more and more companies appreciate the business model, in which the reference point is the concept of an agile company. The selected definitions capture agility in the categories of proactive activities taken by organizations and treat it as the ability to adapt to the changing environment. Thus, business model maturity is mainly perceived through the prism of agility identified with an organization's ability to obtain a competitive advantage, owing to the intelligent, fast, and proactive use of chances in the environment and appropriate response to threats. Although the activities are characterized as intensive learning and the acquisition of skills useful to ensure strategic and effective operation, their spectrum has not been completely exhausted. This problem should be further analyzed (Table 5).

The concept aimed at achieving a competitive advantage in the changing environment is agility. Through perceived options of activities within the configured business model, it is perceived as the ability to "manage uncertainty." In this sense, agility is the ability to change and configure available options in order to accommodate unforeseen circumstances in the environment (the average rating of 3.48; $25.3 \%$ of all indications for the assessment of five points). Customer satisfaction is the objective of a company that - owing to the necessary acquired skills - can respond appropriately to changes occurring in the economic environment. To obtain full satisfaction, a company must acquire distinctive competencies that create the possibility of a quick and effective response to the market changes, which are largely driven by products and services designed by clients (the average rating of 3.46; $23.1 \%$ of indications for the assessment of five points).

The experience of theory and management practices allows us to distinguish two different - albeit basically opposite - approaches to the reconfiguration process of the business model. The first one (the revolutionary approach) suggests a quick and radical break with the past, while the second one (the evolutionary approach) suggests a change in the form of slow and gradual modification of the existing state of affairs. The success of the change depends on the coherent set of practices and structures that interact with each other creating the added value desired by the client. Whether revolutionary or evolutionary, the organizational objective is pointed out, which boils down to establishing regulations so as to ensure the adaptation of the company and environment in a situation of constant changes; therefore, it is also a way to maintain the dynamic 
balance of the organization (the average rating of $3.45 ; 17.6 \%$ of all indications for the assessment of five points).

Table 5. Definitions of high interdependence/relationship: own study results

\begin{tabular}{|c|c|c|c|c|c|c|c|c|}
\hline \multirow{3}{*}{ Item } & \multirow{3}{*}{$\mathbf{F}_{\mathrm{L}} / \mathbf{A}_{\mathbf{G}}$} & \multirow{3}{*}{ DEFINITION AUTHOR } & \multicolumn{5}{|c|}{ \% OF INDICATIONS } & \multirow{3}{*}{$\bar{x}$} \\
\hline & & & \multicolumn{5}{|c|}{ FEATURE VALUE } & \\
\hline & & & 1 & 2 & 3 & 4 & 5 & \\
\hline \multirow{2}{*}{27.} & \multirow{2}{*}{$A_{G}$} & \multirow{2}{*}{ Bernardes, Hanna } & 2.0 & 18.0 & 28.0 & 20.0 & 23.0 & \multirow{2}{*}{3.48} \\
\hline & & & 2.2 & 19.8 & 30.8 & 22.0 & 25.3 & \\
\hline \multirow{2}{*}{28.} & \multirow{2}{*}{$A_{G}$} & \multirow{2}{*}{ Gunasekaran } & 1.0 & 17.0 & 33.0 & 19.0 & 21.0 & \multirow{2}{*}{3.46} \\
\hline & & & 1.1 & 18.7 & 36.3 & 20.9 & 23.1 & \\
\hline \multirow{2}{*}{29.} & \multirow{2}{*}{$\mathrm{F}_{\mathrm{L}}$} & \multirow{2}{*}{ Heinen } & 3.0 & 14.0 & 29.0 & 29.0 & 16.0 & \multirow{2}{*}{3.45} \\
\hline & & & 3.3 & 15.4 & 31.9 & 31.9 & 17.6 & \\
\hline \multirow{2}{*}{30.} & \multirow{2}{*}{$\mathrm{F}_{\mathrm{L}}$} & \multirow{2}{*}{ Juchnowicz } & 3.0 & 19.0 & 27.0 & 20.0 & 22.0 & \multirow{2}{*}{3.43} \\
\hline & & & 3.3 & 20.9 & 29.7 & 22.0 & 24.2 & \\
\hline \multirow{2}{*}{31.} & \multirow{2}{*}{$A_{G}$} & \multirow{2}{*}{ Meredith, Francis } & 3.0 & 13.0 & 36.0 & 23.0 & 16.0 & \multirow{2}{*}{3.40} \\
\hline & & & 3.3 & 14.3 & 39.6 & 25.3 & 17.6 & \\
\hline \multirow{2}{*}{32.} & \multirow{2}{*}{$\mathrm{F}_{\mathrm{L}}$} & \multirow{2}{*}{ Eppink } & 4.0 & 11.0 & 41.0 & 21.0 & 14.0 & \multirow{2}{*}{3.33} \\
\hline & & & 4.4 & 12.1 & 45.1 & 23.1 & 15.4 & \\
\hline \multirow{2}{*}{33.} & \multirow{2}{*}{$\mathrm{F}_{\mathrm{L}}$} & \multirow{2}{*}{ Aaker, Mascarenha } & 3.0 & 20.0 & 35.0 & 18.0 & 15.0 & \\
\hline & & & 3.3 & 22.0 & 38.5 & 19.8 & 16.5 & $3 . \angle 4$ \\
\hline & & & 6.0 & 20.0 & 31.0 & 17.0 & 17.0 & \\
\hline 34. & $r_{L}$ & Quin! & 6.6 & 22.0 & 34.1 & 18.7 & 18.7 & $3 . \angle 1$ \\
\hline & & Вет Kосоnon & 3.0 & 20.0 & 41.0 & 16.0 & 11.0 & 212 \\
\hline 35. & $r_{L}$ & D0z, hosomen & 3.3 & 22.0 & 45.1 & 17.6 & 12.1 & 3.13 \\
\hline & & & 6.0 & 20.0 & 38.0 & 16.0 & 11.0 & \\
\hline 30. & $I_{\mathrm{L}}$ & Lapen & 6.6 & 22.0 & 41.8 & 17.6 & 12.1 & 0.07 \\
\hline
\end{tabular}

Source: own elaboration based on Niewiadomski (2016), Trzcieliński (2011), Baker (1996), Sajdak (2013).

The successful adaptation and creation of sustainable companies significantly affect the ability to create more environmentally and socially integrated economic systems. Sustainable business models are the key element of this objective (Jabłoński, 2018). 
However, the development of sustainable business models is a complex process that requires from the company the capability and potential readiness to adapt to new, various, or changing conditions, tasks, and situations of cognitive and social nature, but also to initiate changes (the average rating of $3.43 ; 24.2 \%$ of all indications for the assessment of five points).

Due to the high market saturation and quickly changing environment, it is important to know what to produce, how to produce, and how and to whom sell this product. Therefore, it is indispensable to make quick and effective knowledge-based decisions founded on available information. A knowledge-based manufacturer is particularly interested in participation in the implementation of operational processes - the analysis of market and client expectations, product manufacturing, marketing, delivery, and sales - as part of product management and support processes, i.e. the management of innovative and information systems related to products and the implementation of environmental programs.

These processes enable companies to learn about the needs of consumers and survey their satisfaction, as they are a starting point for improving production and introducing changes. The implementation of these processes requires, on the one hand, the knowledge of technology, composition, properties of goods, and needs of consumers while, on the other hand, the use of appropriate analytical methods (Niewiadomski, 2016). In the context of the above, in order to support the "market adaptation" strategy, the intelligent mobilizing and managing all forms of knowledge appears among the studied companies (the average rating of $3.40 ; 17.6 \%$ of all indications for the assessment of five points).

Knowledge enables the development of other organizational resources and their impact on the visible effects of company activities. The knowledge-based business model highlights the feature of companies that makes it less sensitive to unpredictable external changes or puts it in a better position so that it can effectively respond to these changes (the average rating of 3.33; 15.4\% of all indications for the assessment of five points).

Knowledge as a resource should be subject to constant identification, measurement, acquisition, development, use, and protection; in other words, knowledge should be subject to appropriate management processes. Attention is drawn to an intelligent business model that, based on knowledge, creates the ability to adapt to extensive, unpredictable, and rapidly occurring changes in the environment that affect the organization's results (the average rating of $3.24 ; 16.5 \%$ of all indications for the assessment of five points). Such a business model includes maintaining certain options owing to 
the wide specification of objectives and allowing new approaches to compete with each other as long as possible (the average rating of $3.21 ; 18.7 \%$ of all indications for the assessment of five points).

The modern manufacturer must identify, diagnose, and project implemented business models. A description of the process of scientific and practical verification of their conditions and the combination of their transformations is to help companies formulate responses to sources of survival and development within the modern economy (Nogalski, 2009). Therefore, the studied companies paid attention to the ability to create, use, and transform existing business models into new ones as tools for strategic reorientation (the average rating of $3.13 ; 12.1 \%$ of all indications for the assessment of five points). Therefore, we postulate that the issue of business models and their use should - in the near future - become a priority of scientific recognition in the sphere of helping management and quality sciences and contemporary enterprises.

An inseparable element of management - or, more precisely, the process of formulating business models - is uncertainty and risk. Hence, companies seek management models oriented toward effective management strategy development by defining the operating procedures and standards. Therefore, our business model definition bases on building an activity path that guarantees efficiency and the shortest implementation time. Its uniqueness is conditioned by the changing reality (environment), which directly or indirectly affects the time and mode of this project's implementation. The model consists of activities arranged in a logical sequence that successively follow each other. Since the risk level of the taken decision is variable, lasts over time, and depends on the threats that appear in the environment, companies pay attention to the accurate definition of an organization's features that allow for effective management under conditions of uncertainty (the average rating of $3.07 ; 12.1 \%$ of all indications for the assessment of five points).

As part of the assessment made on the basis of 40 ordered desiderata, a total of 10 definitions (25\%) were allocated to the group with medium interdependence with the business model. The conducted studies allow us to clearly state that the business models within this group are perceived through the prism of flexibility (70\%). Only three out of ten definitions emphasize the agility category (30\%).

In companies that keep up with the changing market environment and new approaches to management that take into account the value for the company and the buyer, changes are needed in practiced marketing organization methodology. Hence, companies seek new forms of marketing organization to replace the classic business model based on 
the company's internal resources. They seek solutions that are more flexible, use specialized external resources (e.g. in building task teams), employ electronic forms of communication (e.g. in building virtual marketing teams), and base on building relationships with external entities (e.g. suppliers, partners, clients). The marketing of the future focuses on creating and maintaining inter-organizational relationships, cooperation, and dialog. The benefits that arise for entities involved in the network cooperation include, among other things, an increase in knowledge, product development, distribution and promotion system development, and the reduction of costs. Therefore, from the perspective of the future, marketing will be created based on network connections. The above directions of changes in the organization of marketing involve going "outside" of the company in search of specialized resources and competences in the environment. According to the respondents' opinion, this considers a set of related changes in marketing, production, design, and organization (the average rating of $2.98 ; 9.90 \%$ of all indications for the assessment of five points).

The ability to use potential opportunities and create one's own capabilities and predispositions for self-improvement becomes the basis of company development. The absence of such conditions or their relative instability deepens development disparities, thus leading to the relative marginalization of some companies in relation to others in terms of competitive advantage. Such a situation raises the growing need for companies to focus on processes related to the use of knowledge and information architecture in decision-making processes (the average rating of $2.96 ; 11.0 \%$ of all indications for the assessment of five points). The key competence is to attract and maintain appropriate employees and make the best use of their knowledge. All this requires the creation of new authority structures and ways of practicing control (the average rating of 2.96; $7.70 \%$ of all indications for the assessment of five points).

In order to assess the truthfulness and vigilance of the respondents, a control (checking) question was prepared; here, flexibility was defined through the prism of engineering and technical sciences, treating of the material's ability to return to its original shape after cessation of deformation forces (the average rating of 2.95; $8.80 \%$ of all indications for the assessment of five points). The question was of filtering (selective) nature; it enabled us to exclude from the study people who did not meet certain conditions we set.

As part of the assessment made based on 40 ordered desiderata, a total of four definitions $(10 \%)$ were classified into the group with low interdependence with the business model. The conducted studies allow us to clearly state that the business models within this group are perceived equally through the prism of flexibility (50\%) and agility 
(50\%). Herein, two out of four definitions emphasize the agility category, while two stress flexibility.

Table 6. Definitions of high interdependence/relationship: own study results

\begin{tabular}{|c|c|c|c|c|c|c|c|c|}
\hline \multirow{3}{*}{ Item } & \multirow{3}{*}{$\mathbf{F}_{\mathrm{L}} / \mathbf{A}_{\mathbf{G}}$} & \multirow{3}{*}{ DEFINITION AUTHOR } & \multicolumn{5}{|c|}{$\%$ OF INDICATIONS } & \multirow{3}{*}{$\overline{\mathrm{X}}$} \\
\hline & & & \multicolumn{5}{|c|}{ FEATURE VALUE } & \\
\hline & & & 1 & 2 & 3 & 4 & 5 & \\
\hline \multirow{2}{*}{37.} & \multirow{2}{*}{$A_{G}$} & \multirow{2}{*}{ Storey } & 5.0 & 21.0 & 45.0 & 11.0 & 9.0 & \multirow{2}{*}{2.98} \\
\hline & & & 5.5 & 23.1 & 49.5 & 12.1 & 9.9 & \\
\hline \multirow{2}{*}{38.} & \multirow{2}{*}{$A_{G}$} & \multirow{2}{*}{ Dove } & 4.0 & 24.0 & 45.0 & 8.0 & 10.0 & \multirow{2}{*}{2.96} \\
\hline & & & 4.4 & 26.4 & 49.5 & 8.8 & 11.0 & \\
\hline \multirow{2}{*}{39.} & \multirow{2}{*}{$\mathrm{F}_{\mathrm{L}}$} & \multirow{2}{*}{ Sennett } & 3.0 & 24.0 & 45.0 & 12.0 & 7.0 & \multirow{2}{*}{2.96} \\
\hline & & & 3.3 & 26.4 & 49.5 & 13.2 & 7.7 & \\
\hline \multirow{2}{*}{40.} & \multirow{2}{*}{$\mathrm{F}_{\mathrm{L}}$} & \multirow{2}{*}{ Krupski } & 3.0 & 29.0 & 37.0 & 14.0 & 8.0 & \multirow{2}{*}{2.95} \\
\hline & & & 3.3 & 31.9 & 40.7 & 15.4 & 8.8 & \\
\hline
\end{tabular}

Source: own elaboration based on Niewiadomski (2016), Trzcieliński (2011), Baker (1996), Sajdak (2013).

An organization's flexibility and agility may contribute to its easier adaptation to changes in the environment and reduction of the risk associated with making possible mistakes. The lack of a rigid structure, variable sizes, and the non-reliance only on material resources allow it to dynamically change under the influence of the environment, without generating unnecessary costs.

In reference to the above, we emphasize the importance of creative activity for the effective conduct of development processes conditioned by an appropriate degree of an organization's flexibility and agility. Following the scientific discourse conducted in this study, one could be tempted to state that agility and flexibility are interdependent concepts. The deeper content of these issues is inseparably linked to a change in the production profile adequately to the current market needs, which justifies the use of, among other things, new management methods and highly efficient, effective technological devices. Agility refers to the very act of creating new and useful ideas, thoughts, or concepts. On the other hand, flexibility covers processes of both generating and adapting relevant resources - in the context of a given implementation - but also the 
effective use of creative ideas in a commercial context. In this sense, both agility and flexibility are fundamental to the effective management of implementation processes.

Today, it is the consumer who is significantly involved in co-creating and promoting products or the simultaneous production and consumption of manufactured goods. In this sense, as an active player on the market, the consumer becomes the co-creator of the business model activated by the manufacturer. The distinct difference between the consumer and producer ceases to be so obvious these days compared to how it was in the past. The problem is that the way consumer choices are made is transferred to the sphere of production. Rationality adequate to the market conditions colonizes other areas of the functioning of entities; it applies both to product choices and the broader understood sense of involvement in creating the production portfolio.

The results of the conducted research allow us to say that the implementation of flexibility and agility implies the quality of the market offer, which contributes to the growth of the company's value on a given market or the improvement of its competitive position, which becomes the key challenge for modern companies that adopt business models.

\section{Conclusion}

Currently, it is difficult to imagine a long-term orientation of organizations without identifying new ways of conducting business activities and developing new technologies and products or entering new markets in new organizational forms. The currently functioning manufacturer with aspirations for stable functioning and development must implement completely new ways to earn money or improve those already defined. Our deliberations prove the point and purposefulness of such a construct of business models that take the market adaptation perspective as their starting point. However, let us note that this is not one of another management fashions, but a necessity dictated by the specificity of highly competitive principles in the agricultural machinery market at almost every level: local, national, and international.

The purpose of our considerations in this article was to recognize whether the maturity of the business model is viewed through the prism of agility or flexibility. The reconnaissance of opinions required the creation of a catalog of desiderata that meaningfully identify agility and flexibility. Our theoretical and design layers used a method of reconstruction and interpretation of the subject literature supported by a discussion within a group of deliberately selected experts. This is reflected in a set of parameters, on the one hand, characteristic of the category of agility and flexibility and, on the other 
hand, reflecting business model maturity. At the empirical level, it was important to determine to what extent the suggested properties reflect the sense of the concept in the context of an intensive search of market opportunities emerging in the environment.

The material collected during the research procedure allowed us to verify the presumption and draw conclusions of a general and cognitive nature. The presumption assumed in the article has been confirmed in their entire extent in the conducted theoretical and empirical argument (Table 7).

\section{Table 7. Results of presumption testing}

\section{Presumption}

Testing result

$\mathbf{P}_{1}$ : Although more and more companies appreciate the business model in which the reference point is the concept of an agile or flexible company, business model maturity is mainly perceived through the prism of agility, identified with the organization's ability to obtain a competitive advantage owing to the intelligent, fast, and proactive use of chances in the environment and appropriate response to threats.

$\mathbf{P}_{2}$ : The agility and flexibility desiderata of a manufacturing company in the agricultural machinery sector can be prioritized.

$\mathbf{P}_{3}$ : Substantially, the agility defined as the ability to manufacture and effectively offer a wide range of low-cost and high-quality products in a short time period and full range of sizes - owing to which the company creates value for clients through customization - is a concept aimed at achieving competitive advantage in a dynamic environment.

$\mathbf{P}_{\mathbf{4}}$ : There is a difference between company agility and flexibility; agility is a wider concept of analysis.

$\mathbf{P}_{5}$ : A uniform and commonly accepted definition of flexibility and agility has not been created yet.

$\mathbf{P}_{6}$ : Not all diagnosed desiderata of agility and flexibility are important in the conceptualization of a mature business model. There are factors of both primary and secondary importance.

$\mathbf{P}_{\mathbf{7}}$ : The building of flexible company models can base on existing methodological approaches.

$\mathbf{P}_{\mathbf{8}}$ : Flexibility is a derivative of resources available for manufacturers, market expectations, and tasks and operating conditions of organizational managers.

Source: own elaboration.

The conducted research allows us to state that mature (as implemented by the surveyed companies) business models are perceived rather through the prism of the strategic 
ability of enterprises to quickly adapt to unforeseen and sudden changes on the market (agility category). As part of the assessment conducted based on 26 desiderata, 15 (57.69\%) definitions reflecting agility were qualified to the group with a high correlation with a mature business model (5.00-3.50), while 11 referred to the flexibility category (42.31).

As part of the assessment based on 10 successively hierarchical desiderata, a group with average interdependence with the business model (3.49-2.50) was assigned a total of 10 definitions, of which only three (30\%) highlight the agility category. As part of the assessment performed based on four desiderata classified within the group with low interdependence with the business model (2.49 and less), the category of agility and flexibility was equally emphasized.

The above deliberations show a specific cause-and-effect dependencies' sequence, essential for the development of manufacturing companies. Its development requires a permanent commitment of all employees and the maximum mobilization of resources at its disposal. The knowledge increase of a single employee/manager and his/her positive attitude toward customer environment issues contribute to the entire organization's development.

Therefore, knowledge management systems should be implemented and truly followed. Such a condition improves the current company's functioning through joint strategic discussions and joint works on its vision. Furthermore, it is important to constantly prioritize, track progress, solve dilemmas, and model business development paths. Despite the current turbulent environment and variable surroundings - but also pervasive uncertainties - the twenty-first century is not unusual in this regard. In the light of the above, we state with full responsibility that issues related to organization agility and flexibility are not dictated by the moment, but they are, were, and will be among the basic issues related to strategic management theory and practice.

In this article, management is considered as a science, whose effect is socially useful knowledge in the form of fixed economic life regularities and theories that explain the reality field, provide projects to be applied, and help in rationalizing this reality. 


\section{References}

Aaker, D.A. and Mascarenhas, B. (1984). The need for strategic flexibility. Journal of Business Strategy, 5(2), 74-82. https://doi.org/10.1108/eb039060.

Adler, P.S., Goldoftas, B. and Levine, D.I. (1999). Flexibility versus Efficiency? A Case Study of Model Changeovers in the Toyota Production System. Organization Science, 10(1), 43-68. https://doi.org/10.1287/orsc.10.1.43.

Atkinson, J. (1984). Manpower strategies for flexible organizations. Personnel Management, 26, 28-31.

Avittathur, B. and Swamidass, P. (2007). Matching plant flexibility and supplier flexibility: lessons from small suppliers of US manufacturing plants in India. Journal of Operations Management, 25(3), 717-735. https://doi.org/10.1016/j.jom.2006.05.015.

Baker, J. (1996). Agility and Flexibility: What`s Difference? Cranfield School of Management Working Papers Series, 5, 1-7.

Barrand, J. (2006). Le Manager agile, Vers un nouveau management pour affronter la turbulence. Paris: Dunod.

Benzies, K.M., Premji, S., Hayden, K.A. and Serrett, K. (2006). State of the evidence reviews: Advantages and challenges of including grey literature. Worldviews on Evidence Based Nursing, 3(2), 55-61. https://doi.org/10.1111/j.1741-6787.2006.00051.x.

Bernardes, E.S. and Hanna, M.D. (2009). A Theoretical review of flexibility, agility and responsiveness in the operation management literature. International Journal of Operations \& Productions Management, 29(1), 30-53. https://doi.org/10.1108/01443570910925352.

Bhattacharya, M., Gibson, D.E. and Doty, D.D. (2005). The effects of flexibility in employee skills, employee behaviors, and human resource practices on firm performance. Journal of Management, 31(4), 622-640. https://doi.org/10.1177/0149206304272347.

Breu, K., Hemingway, C.J., Strathern, M. and Bridger, D. (2001). Workforce agility: The new employee strategy for the knowledge economy. Journal of Information Technology, 17(1), 21-31. https://doi.org/10.1080/02683960110132070.

Brown, P., Ly, T., Pham, H. and Sivabalan, P. (2020). Automation and management control in dynamic environments: Managing organizational flexibility and energy efficiency in service sectors. The British Accounting Review, 52(2). https://doi.org/10.1016/j.bar.2019.100840.

Brown, S.L. and Eisenhardt, K.M. (1998). Competing on the Edge. Strategy as a structural chaos. Boston: Harvard Business School Press. https://doi.org/10.1016/S0024-6301(98)00092-2.

Bruce, M., Daly, L. and Towers, N. (2004). Lean or agile: a solution for supply chain management in the textiles and clothing industry? International Journal of Operations and Production Management, 24(2), 151-170. https://doi.org/10.1108/01443570410514867.

Cegarra-Navarro, J-G., Soto-Acosta, P. and Wensley, A.K.P. (2016). Structured knowledge processes and firm performance: The role of organizational agility. Journal of Business Research, 69(5), 1544-1549. https://doi.org/10.1016/j.jbusres.2015.10.014.

Columb, M.O. and Lalkhen, A.G. (2005). Systematic reviews \& meta-analyses. Current Anaesthesia \& Critical Care, 16(6), 391-394. https://doi.org/10.1016/j.cacc.2006.02.004.

Conn, V.S., Valentine, J.C., Cooper, H.M. and Rantz, M.J. (2003). Grey literature in meta-analyses. Nursing Research, 52(4), 256-261. https://doi.org/10.1097/00006199-200307000-00008.

Czakon, W. (2011). Metodyka systematycznego przeglądu literatury. Przegląd Organizacji, 3, 57-61. https://doi.org/10.33141/po.2011.03.13.

D’Souza, D.E. and Williams, F.P. (2000). Toward a taxonomy of manufacturing flexibility dimensions. Journal of Operations Management, 18(5), 577-593. https://doi.org/10.1016/S0272-6963(00)00036-X. 
Darvishmotevali, M., Altinay, L. and Köseoglu, M.A. (2020). The link between environmental uncertainty, organizational agility, and organizational creativity in the hotel industry. International Journal of Hospitality Management, 87. https://doi.org/10.1016/j.ijhm.2020.102499.

Dove, R. (2001). Response ability. New York: Wiley.

Doz, Y. and Kosonen, M. (2008). Fast Strategy. How strategic agility will help you stay ahead of the game. Great Britain: Wharton School Publishing.

Doz, Y. and Kosonen, M. (2010). Embedding Strategic Agility. A Leadership Agenda for Accelerating Business Model Renewal. Long Range Planning, 43(2-3), 370-382. https://doi.org/10.1016/j.lrp.2009.07.006.

Eapen, G. (2010). Flexibility. Flexible Companies for the Uncertain World. Boca Raton: CRC Press. https://doi.org/10.1201/9781439816332.

Ebben, J.J. and Johnson, A.C. (2005). Efficiency, Flexibility, or Both? Evidence Linking Strategy to Performance in Small Firms. Strategic Management Journal, 26(13), 1249-1259. https://doi.org/10.1002/smj.503.

Engelhardt, H., Kohler, H.P. and Fürnkranz-Prskawetz, A. (2009) (eds.). Causal analysis in population studies: Concepts, methods, applications. Dordrecht, Netherlands: Springer.

Evans, J.S. (1991). Strategic flexibility for high technology manoeuvres. A conceptual framework. Journal of Management Studies, 28(1), 69-89. https://doi.org/10.1111/j.1467-6486.1991.tb00271.x.

Faratash, K. and Davoudi, S.M. (2012). The important role of strategic agility in firms capability and performance. International Journal of Engineering and Management Research, 2(3).

Fayezi, S., Zutshi, A. and O'Loughlin, A. (2015). How Australian manufacturing firms perceive and understand the concepts of agility and flexibility in the supply chain. International Journal of Operations and Production Management, 35(2), 246-281.

https://doi.org/10.1108/IJOPM-12-2012-0546.

Feldman, M.S. and Pentland, B.T. (2003). Reconceptualizing Organizational Routines as a Source of Flexibility and Change. Administrative Science Quarterly, 48(1), 94-118. https://doi.org/10.2307/3556620.

Gerwin, D. (1987). An Agenda for Research on the Flexibility of Manufacturing Processes. International Journal of Productions Management, 7(1), 38-49. https://doi.org/10.1108/eb054784.

Gimenez, C. and Tachizawa, E. (2012). Extending sustainability to suppliers: a systematic literature review. Supply Chain Management: An International Journal, 17(5), 531-543. https://doi.org/10.1108/13598541211258591.

Goriwondo, W.M., Mhlanga, S. and Mutsambwa, T. (2013). Agility for sustainability in Zimbabwe: A case study for manufacturing companies in Bulawayo, China - USA. Business Review, 12(1). https://doi.org/10.17265/1537-1514/2013.01.005.

Gunasekaran, A. (1998). Agile manufacturing: enablers and an implementation framework. International Journal of Production Research, 36(5), 1223-1247. https://doi.org/10.1080/002075498193291.

Harrigan, K.R. (1985). Strategic Flexibility. A Management Guide for Changing Times. Massachusetts: Lexington Books.

Hormozi, A.M. (2009). Agile manufacturing: the next logical step. Benchmarking, 8(2), 132-143. https://doi.org/10.1108/14635770110389843.

Jabłoński, A. (2018). Twórczy model biznesu w koncepcji gospodarki sieciowej. Studia i Prace Naukowe Kolegium Zarzq̨dzania i Finansów, 162, 175-192.

Jemielniak, D. and Latusek, D. (2005). Zarzqdzanie: teoria i praktyka od podstaw. Warszawa: WSPiZ im. Leona Koźmińskiego. 
Jemielniak, D. and Koźmiński, A.K. (2011). Zarzq̨dzanie od podstaw. Warszawa: Wolters Kluwer Polska.

Jones, R.A. and Ostroy, J.M. (1984). Flexibility and uncertainty. The Review of Economic Studies, 51(1), 13-32. https://doi.org/10.2307/2297702.

Kannan, D., Khodaverdi, R., Olfat, L., Jafarian, A. and Diabat, A. (2013). Integrated fuzzy multi criteria decision making method and multi-objective programming approach for supplier selection and order allocation in a green supply chain. Journal of Cleaner Production, 47, 355-367. https://doi.org/10.1016/j.jclepro.2013.02.010.

Kidd, P.T. (1994). Agile Manufacturing: Forging New Frontiers. Boston: Addison-Wesley.

King, W. R. and He, J. (2005). Understanding the role and methods of meta-analysis in IS research. Communications of the Association for Information Systems, 16(1), 665-686. https://doi.org/10.17705/1CAIS.01632.

Korzyński, P. (2013). Employee Motivation In New Working Environment. International Journal of Academic Research, 5, 184-188. https://doi.org/10.7813/2075-4124.2013/5-5/B.28.

Korzyński, P. (2014). Overcoming Leadership Limitations: A Theoretical Study of Leadership Behaviors and Methods. Management and Business Administration. Central Europe, 4(127), 26-38. https://doi.org/10.7206/mba.ce.2084-3356.116.

Koste, L.L. and Malhotra, A. (1999). Theoretical Framework for Analyzing the Dimensions of Manufacturing Flexibility. Journal of Operations Management, 18, 75-93. https://doi.org/10.1016/S0272-6963(99)00010-8.

Koźmiński, A.K. (2013). Ograniczone przywództwo. Studium empiryczne. Warszawa: Poltext.

Krupski, R. (2005). Zarzq̨dzanie przedsiębiorstwem w turbulentnym otoczeniu. Ku superelastycznej organizacji. Warszawa: Polskie Wydawnictwo Ekonomiczne.

Levy, Y. and Ellis, T.J. (2006). A systems approach to conduct an effective literature review in support of information systems research. Informing Science Journal, 9, 181-212. https://doi.org/10.28945/479.

Lockamy III, A. and McCormack, K. (2004). The development of a supply chain management process maturity model using the concepts of business process orientation. Supply Chain Management, 9(4), 272-278. https://doi.org/10.1108/13598540410550019.

Lynch, J.G. (1989). Organizational flexibility. HR. Human Resource Planning, 12, 21-27.

May; Zhou, J., Bi, G., Liu, H., Fang, J. and Hua, Z. (2018). Understanding employee competence, operational IS alignment, and organizational agility - An ambidexterity perspective. Information \& Management, 55(6), 695-708. https://doi.org/10.1016/j.im.2018.02.002.

Mehrabi, S.S. (2013). Examining the degree of organizational agility from employees' perspective (Agriculture - Jahad Organization of Shahrekord City). Academic Research in Business and Social Sciences, 9(3), 315-323. https://doi.org/10.6007/IJARBSS/v3-i9/237.

Meredith, S. and Francis, D. (2000). Journey towards agility: The agile wheel explored. The TQM Magazine, 12(2), 137-143. https://doi.org/10.1108/09544780010318398.

Nabatchian, G.M. (2014). Review the relation between organizational agility and job satisfaction of staff in the Ministry of Youth Affairs and Sports Iran. Modern Communication Technologies \& Research (IJMCTR), 2(2), 10-13.

Nenni, M.E., Arnone, V., Boccardelli, P. and Napolitano, I. (2014). How to Increase the Value of the Project Management Maturity Model as a Business-oriented Framework. International Journal of Engineering Business Management, 6, 1-7. https://doi.org/10.5772/58292.

Ng, I. and Dastmalchian, A. (2001). Organizational flexibility in Western and Asian firms: An examination of control and safeguard rules in five countries. Canadian Journal of Administrative Sciences, 18(1), 17-24. 
Nichols, J. (2012). Management: Everything must change. But how? Keeping Good Companies, 64(2), $118-120$.

Nickpour, A. and Salajegheh, S. (2011). An investigation of the relationship between organizational agility and job satisfaction of employees' of Governmental Organization of Kerman. Research in Management, 15(1), 85-97.

Niewiadomski, P. (2016). Determinanty elastyczności funkcjonowania przedsiębiorstwa produkcyjnego sektora maszyn rolniczych. Poznań: Wydawnictwo Politechniki Poznańskiej.

Nogalski, B. (2009). Modele biznesu jako narzędzia reorientacji strategicznej przedsiębiorstw. MBA, 2, 3-14.

Norman, R. and Stockport, G.J. (2009). Defining strategic flexibility. Global Journal of Flexible Systems Management, 10, 27-32. https://doi.org/10.1007/BF03396553.

Obłój, K. (2014). Strategia organizacji. Warszawa: PWE.

Obłój, K. (2016). Pasja i dyscyplina strategii. Warszawa: Poltext.

Obłój, K. (2017). Praktyka strategii firmy. Warszawa: Poltext.

Olhager, J. (1993). Manufacturing Flexibility and Profitability. International Journal of Productions Economics, 30-31, 67-78. https://doi.org/10.1016/0925-5273(93)90082-V.

Osterwalder, A., Pigneur, Y. and Tucci, C.L. (2005). Clarifying Business Models: Origins, Present, and Future of The Concept. Communications of the Association for Information Systems, 15, 1-25. https://doi.org/10.17705/1CAIS.01601.

Paulus, P.B., Dzindolet, M.T., Poletes, G. and Camacho, L.M. (1993). Perception of performance in group brainstorming: The illusion of group productivity. Personality and Social Psychology Bulletin, 19, 78-89. https://doi.org/10.1177/0146167293191009.

Raschke, R.L. (2010). Process view of agility: The value contribution of IT and the effects on process outcomes. International Journal on Accounting Information Systems, 11, 297-313. https://doi.org/10.1016/j.accinf.2010.09.005.

Sajdak, M. (2013). An agile, lean or flexible enterprises - Are they synonymous or different notions? In: S. Trzcieliński (ed.), Chosen problems of management. Issues on present and the future. Poznań: Publishing House of Poznań University of Technology.

Santos Bernardes, E. and Hanna, M.D. (2009). A Theoretical review of flexibility, agility and responsiveness in the operation management literature. International Journal of Operations $\&$ Productions Management, 29(1), 30-53. https://doi.org/10.1108/01443570910925352.

Sarkis, J. (2001). Benchmarking for agility. Benchmarking. An International Journal, 8(2), 88-107. https://doi.org/10.1108/14635770110389816.

Sehnem, S., Campos, L.M.S., Julkovski, D.J. and Cazella, C.F. (2019). Circular business models: level of maturity. Management Decision, 57, 1043-1066. https://doi.org/10.1108/MD-07-2018-0844.

Sethi, A. and Sethi, S. (1990). Flexibility Manufacturing: a Survey. The International Journal of Flexible Manufacturing Systems, 2(4), 289-328. https://doi.org/10.1007/BF00186471.

Sharifi, H. and Zhang, Z.A. (1999). Methodology for Achieving Agility in Manufacturing Organizations: An introduction. International Journal of Production Economics, 62(1/2), 7-22. https://doi.org/10.1016/S0925-5273(98)00217-5.

Sharifi, H., Colquhoun, G., Barclay, I., and Dann, Z. (2001). Agile manufacturing: A management and operational framework. Proceedings of the Institution of Mechanical Engineers, Part B: Journal of Engineering Manufacture, 215(6), 857-869. https://doi.org/10.1243/0954405011518647.

Slack, N. (1983). Flexibility as a manufacturing objective. International Journal of Operations \& Production Management, 33, 4-13. https://doi.org/10.1108/eb054696. 
Stańczyk-Hugiet, E. (2008). Elastyczność organizacji - perspektywa zdolności dynamicznych. In: A. Kaleta and K. Moszkowicz (eds.), Zarzqdzanie strategiczne w badaniach teoretycznych i w praktyce. Wrocław: Wydawnictwo Uniwersytetu Ekonomicznego we Wrocławiu.

Sternberg, R.J. and Lubart, T.I. (1999). The concept of creativity: Prospects and paradigms. In: R.J. Sternberg (ed.), Creativity research handbook. New York: Cambridge University Press. https://doi.org/10.1017/CBO9780511807916.003.

Swafford, P.M., Ghosh, S. and Murthy, N.N. (2006). The Antecedents of Supply Chain Agility of a Firm: Scale Development and Model Testing. Journal of Operations Management, 24(2). https://doi.org/10.1016/j.jom.2005.05.002.

Trzcieliński, S. (2011). Przedsiębiorstwo zwinne. Poznań: Wydawnictwo Politechniki Poznańskiej. Upton, D.M. (1994). The Management of Manufacturing Flexibility. California Management Review, 36(2), 72-89. https://doi.org/10.2307/41165745.

Urbanowska-Sojkin, E. (2013). Ryzyko w wyborach strategicznych w przedsiębiorstwach. Warszawa: Polskie Wydawnictwo Ekonomiczne.

Weber, Y. and Tarba, S.Y. (2014). Strategic Agility: A state of the Art, Introduction to the special section on strategic agility. California Management Review, 56(3), 5-12. https://doi.org/10.1525/cmr.2014.56.3.5.

Wood, R.E., Goodman, J.S., Beckmann, N. and Cook, A. (2008). Mediation testing in management research: A review and proposals. Organizational Research Methods, 11(2), 270-295. https://doi.org/10.1177/1094428106297811.

Yukl, G. (2012). Effective Leadership Behaviors: What We Know and What Questions Need More Attention? The Academy of Management Perspectives, 26(4), 66-85. https://doi.org/10.5465/amp.2012.0088.

Yusuf, Y., Sarhadi, M. and Gunasekaran, A. (1999). Agile manufacturing: the drivers, concepts and attributes. International Journal of Production Economics, 62(1/2), 33-43. https://doi.org/10.1016/S0925-5273(98)00219-9.

Zhang, Q., Vonderembse, M.A. and Lim, J.S. (2002). Value chain flexibility: a dichotomy of competence and capability. International Journal of Production Research, 40(3), 561-583. https://doi.org/10.1080/00207540110091695.

Zheng, Z.K. and Wu, F. (2010). Technological capability, strategic flexibility, and product innovation. Strategic Management Journal, 31, 547-561. 